\title{
Radiance-based retrieval bias mitigation for the MOPITT instrument: the version 8 product
}

\author{
Merritt N. Deeter ${ }^{1}$, David P. Edwards ${ }^{1}$, Gene L. Francis ${ }^{1}$, John C. Gille ${ }^{1}$, Debbie Mao ${ }^{1}$, Sara Martínez-Alonso ${ }^{1}$, \\ Helen M. Worden ${ }^{1}$, Dan Ziskin ${ }^{1}$, and Meinrat O. Andreae ${ }^{2,3}$ \\ ${ }^{1}$ Atmospheric Chemistry Observations and Modeling Laboratory, National Center for Atmospheric Research, \\ Boulder, CO, USA \\ ${ }^{2}$ Max Planck Institute for Chemistry, P.O. Box 3060, 55020 Mainz, Germany \\ ${ }^{3}$ Scripps Institution of Oceanography, University of California San Diego, La Jolla, CA 92093-0221, USA
}

Correspondence: Merritt N. Deeter (mnd@ucar.edu)

Received: 4 February 2019 - Discussion started: 5 March 2019

Revised: 26 June 2019 - Accepted: 11 July 2019 - Published: 28 August 2019

\begin{abstract}
The MOPITT (Measurements of Pollution in the Troposphere) satellite instrument has been making nearly continuous observations of atmospheric carbon monoxide (CO) since 2000. Satellite observations of CO are routinely used to analyze emissions from fossil fuels and biomass burning, as well as the atmospheric transport of those emissions. Recent enhancements to the MOPITT retrieval algorithm have resulted in the release of the version 8 (V8) product. V8 products benefit from updated spectroscopic data for water vapor and nitrogen used to develop the operational radiative transfer model and exploit a new method for minimizing retrieval biases through parameterized radiance bias correction. In situ datasets used for algorithm development and validation include the NOAA (National Oceanic and Atmospheric Administration) and HIPPO (HIAPER Pole-to-Pole Observations) datasets used for earlier MOPITT validation work in addition to measurements from the ACRIDICON-CHUVA (Aerosol, Cloud, Precipitation, and Radiation Interactions and Dynamics of Convective Cloud Systems - Cloud processes of the main precipitation systems in Brazil: A contribution to cloud resolving modeling and to the GPM (Global Precipitation Measurement)), KORUS-AQ (The Korea-United States Air Quality Study), and ATom (The Atmospheric Tomography Mission) programs. Validation results illustrate clear improvements with respect to long-term bias drift and geographically variable retrieval bias. For example, whereas bias drift for the V7 thermal-infrared (TIR)-only product exceeded $0.5 \% \mathrm{yr}^{-1}$ for levels in the upper troposphere (e.g., at $300 \mathrm{hPa}$ ), bias drift for
\end{abstract}

the V8 TIR-only product is found to be less than $0.1 \% \mathrm{yr}^{-1}$ at all levels. Also, whereas upper-tropospheric $(300 \mathrm{hPa}) \mathrm{re}-$ trieval bias in the V7 TIR-only product exceeded $10 \%$ in the tropics, corresponding V8 biases are less than $5 \%$ (in terms of absolute value) at all latitudes and do not exhibit a clear latitudinal dependence.

\section{Introduction}

MOPITT (Measurements of Pollution in the Troposphere) is a gas correlation radiometer instrument on the NASA Terra satellite which permits retrievals of $\mathrm{CO}$ vertical profiles using both thermal-infrared (TIR) and near-infrared (NIR) measurements. The MOPITT instrument has been in operation since 2000 (Drummond et al., 2016), resulting in a long-term data record well suited for a variety of applications. Satellite measurements of $\mathrm{CO}$ are used in air quality forecasts (Inness et al., 2015) as well as to estimate CO emissions (e.g., Kopacz et al., 2010; Jiang et al., 2017; Zheng et al., 2018) and to study how fires and urban pollution influence atmospheric chemistry on regional to global scales (e.g., Heald et al., 2003; Edwards et al., 2004; Pfister et al., 2005; Turquety et al., 2007; Shindell et al., 2006; Emmons et al., 2010; Kumar et al., 2013; Gaubert et al., 2017; Miyazaki et al., 2018). Since its launch, MOPITT retrieval products have improved continuously as the result of accumulated knowledge regarding the instrument, radiative transfer modeling methods, and geophysical variables (Worden et al., 2014; Deeter et al., 
2017). Moreover, the availability of new in situ datasets (e.g., from field campaigns) has enabled the quantitative analysis of MOPITT retrieval biases in a variety of contexts. As illustrated below, such in situ datasets may be used to both (1) mitigate temporally and geographically variable retrieval biases and (2) independently validate the resulting $\mathrm{CO}$ product.

MOPITT retrieval products are generated with an iterative optimal-estimation-based retrieval algorithm which involves both the MOPITT calibrated radiances and a priori knowledge of CO variability (Deeter et al., 2003). CO retrievals of $\log (\mathrm{VMR})$ are performed on a retrieval grid with 10 pressure levels (surface, 900, 800, ..., $100 \mathrm{hPa}$ ). Retrieval layers, used internally in the MOPITT retrieval algorithm, are defined by the layers between each level in this grid and the next-highest level in the grid (Francis et al., 2017). For example, the surface-level retrieval product actually represents the mean volume mixing ratio for the layer between the surface and $900 \mathrm{hPa}$. Retrieved CO total column values are calculated directly from the $\mathrm{CO}$ profile and are thus not retrieved independently. A priori $\mathrm{CO}$ profiles are derived from a model climatology and vary seasonally and geographically; the a priori climatology introduced for processing MOPITT version 7 products (Deeter et al., 2017) is unchanged for the new version 8 products described below.

All MOPITT CO retrievals are based on a defined subset of the average (A) and difference (D) radiances from MOPITT channels 5, 6, and 7; each channel is associated with a specific TIR or NIR gas correlation radiometer (Drummond et al., 2010). TIR-only retrievals are based on the 5A, 5D, and $7 \mathrm{D}$ radiances in the $4.7 \mu \mathrm{m}$ band, whereas NIR-only retrievals are based solely on the ratio of the $6 \mathrm{D}$ and $6 \mathrm{~A}$ radiances in the $2.3 \mu \mathrm{m}$ band. MOPITT TIR-only retrievals are typically most sensitive to $\mathrm{CO}$ in the mid- and upper troposphere, except in scenes characterized by strong thermal contrast (Deeter et al., 2007). MOPITT NIR-only retrievals are most useful for retrievals of CO total column (Deeter et al., 2009; Worden et al., 2010). Unique multispectral TIRNIR retrievals exploit the 5A, 5D, 7D, 6D, and 6A radiances. The TIR-NIR product offers greater vertical resolution than TIR-only or NIR-only products and features the greatest sensitivity to CO in the lower troposphere (Deeter et al., 2013). However, because NIR measurements rely on reflected solar radiation, the main benefits of the TIR-NIR product are limited to daytime MOPITT observations over land.

Overall retrieval biases for MOPITT V7 products were previously shown to be less than about $5 \%$ at all retrieval levels for the TIR-only, NIR-only, and TIR-NIR retrievals (Deeter et al., 2017). However, over the MOPITT mission, validation results for $\mathrm{V} 7$ also indicated significant long-term trends in the retrieval biases, i.e., bias drift. For example, V7 TIR-only biases at the 800 and $400 \mathrm{hPa}$ retrieval levels exhibited bias drift of -0.41 and $0.81 \% \mathrm{yr}^{-1}$, respectively. However, opposing drift in the upper and lower troposphere appears to mostly cancel with respect to the retrieved total column (Deeter et al., 2013). Similar drift values for 800 and $400 \mathrm{hPa}$ retrievals are indicated in the updated bias time series plots for the V7 TIR-only product (based on in situ profiles acquired from 2000-2018) shown in Fig. 1; validation methods are described in Sect. 3. Considerations of longterm drift are particularly important for satellite-based analyses of CO long-term trends (Worden et al., 2013).

Moreover, as indicated in Fig. 2, validation results using the HIPPO (HIAPER Pole-to-Pole Observations) dataset (Wofsy et al., 2011) revealed significant latitudinal variability in the V7 TIR-only retrieval biases (Deeter et al., 2017). In the upper troposphere, for example, V7 TIR-only retrieval biases are much larger in the Tropics than outside the Tropics. This effect might, for example, be related to the modeling of water vapor absorption in the MOPITT TIR passband (Edwards et al., 1999) or perhaps to the accuracy of water vapor fields which are used in the MOPITT retrieval algorithm (Pan et al., 1995; Wang et al., 1999). V7 TIR-only retrieval biases derived for the HIPPO dataset are plotted versus water vapor total column (derived from the MERRA-2 reanalysis) in Fig. 3. The figure indicates that retrieval biases increase with increasing water vapor in the upper troposphere but exhibit the opposite behavior in the lower troposphere. Correlation coefficients for this dependence are largest in the upper troposphere $(0.67$ at $200 \mathrm{hPa})$ and lower troposphere $(-0.42$ at $900 \mathrm{hPa})$.

The remaining sections of this paper describe revisions made to the MOPITT version 8 retrieval algorithm (Sect. 2); the validation methodology and results (Sect. 3); and, finally, the conclusions drawn from the results (Sect. 4).

\section{Version 8 retrieval algorithm enhancements}

As detailed in the sections below, the version 8 retrieval algorithm incorporates updated spectroscopic information used in the radiative transfer model; improved methods for radiance bias correction and averaging kernel calculations; and, finally, the most recent version of the MODIS cloud mask.

\subsection{Radiative transfer modeling}

The MOPITT operational retrieval algorithm relies on a fast radiative transfer model, known as MOPFAS, to simulate measured radiances for specified atmospheric and surface conditions (Edwards et al., 1999). Within the MOPITT TIR and NIR filter passbands, measured radiances are sensitive to atmospheric concentrations of several gases including $\mathrm{CO}$, water vapor, and $\mathrm{N}_{2} \mathrm{O}$. Accurate spectroscopic data (e.g., absorption line strengths and line widths) are needed for each of these gases in the development of MOPFAS. For most gases, the V8 operational radiative transfer model is based on the HITRAN2012 spectral database (Rothman et al., 2013), which is the same version of HITRAN used for MOPITT V7 processing. However, spectroscopic data for water vapor 

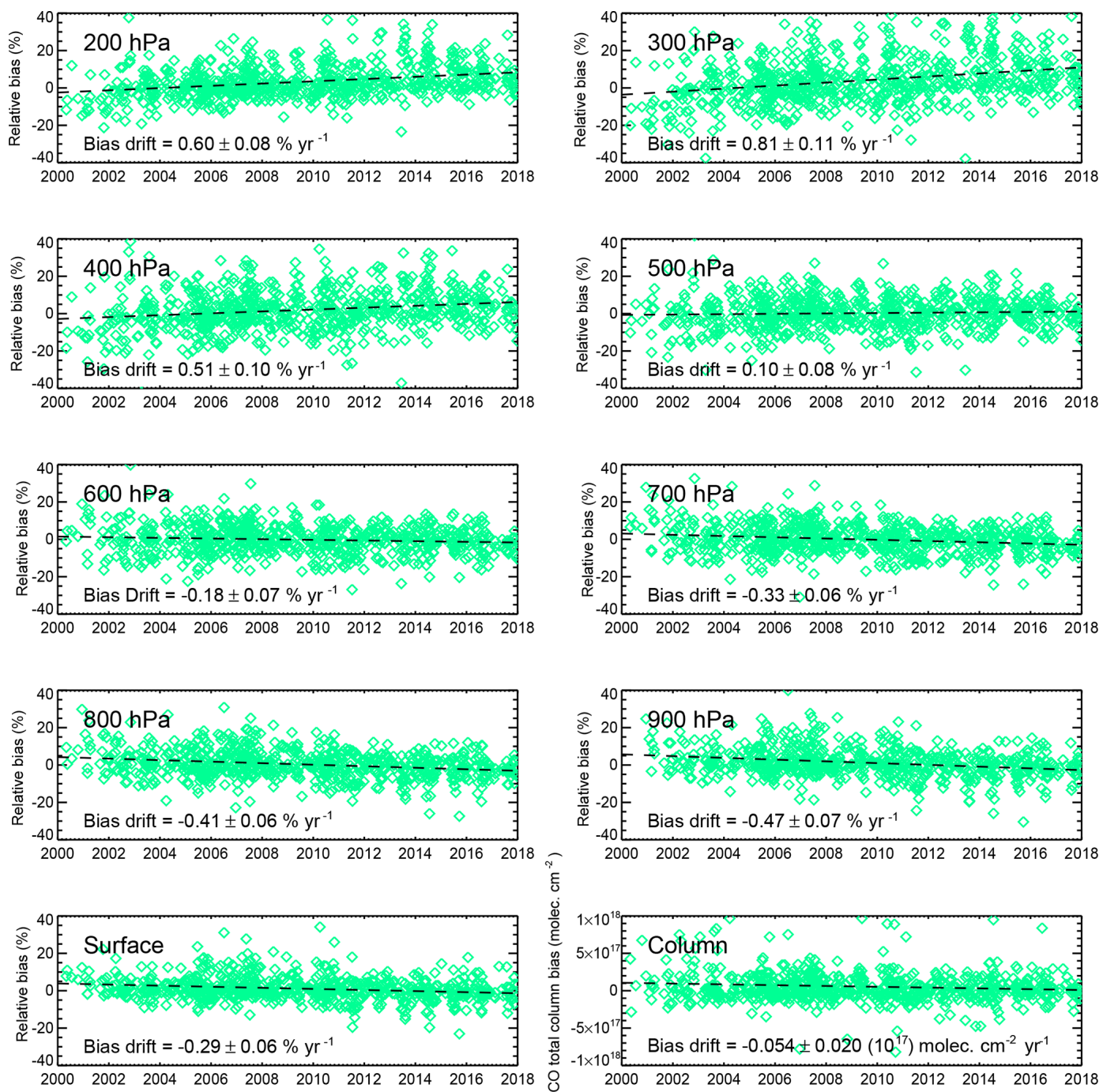

Figure 1. Retrieval bias drift for V7 TIR-only products based on the NOAA flask measurements.

and nitrogen have each been updated for V8. Water vapor continuum absorption in the V8 operational radiative transfer model is based on version 3.2 of the MT_CKD spectroscopic model from AER (Atmospheric and Environmental Research, Inc.; Mlawer et al., 2012), whereas earlier MOPITT radiative transfer models employed version 1.0. The radiative effects of molecular nitrogen, which were not previously represented in MOPFAS, are now derived from the line-by-line model GENLN3 (Edwards, 1992). Absorption by nitrogen in the MOPITT TIR band occurs through collisions between $\mathrm{N}_{2}$ molecules (Richard et al., 2012). A comparison of top-of-atmosphere TIR transmittances for the two models for water vapor continuum absorption, along with the collisionally induced transmittance of nitrogen, is shown in Fig. 4. For water vapor, transmittance differences exceeding $10 \%$ are observed for the two models. The figure also shows that the collisionally induced transmittance of nitrogen varies between approximately $1 \%$ and $10 \%$ across the
MOPITT TIR passband. With respect to radiances integrated over the MOPITT TIR passband, model calculations indicate that the inclusion of both the new water vapor model and collisionally induced nitrogen absorption each produce changes of several percent. In addition, to reflect current tropospheric conditions, the globally fixed concentration of $\mathrm{CO}_{2}$ assumed in the V8 operational radiative transfer model was increased to $410 \mathrm{ppm}$. This change was found to produce a negligible effect (less than $0.05 \%$ ) on the MOPFAS-simulated radiances, however.

\subsection{Radiance bias correction}

The MOPITT Level 2 processor exploits radiance bias correction factors to compensate for relative biases between simulated radiances calculated by MOPFAS and actual calibrated Level 1 radiances from the instrument. Without some form of compensation, radiance biases would produce large 

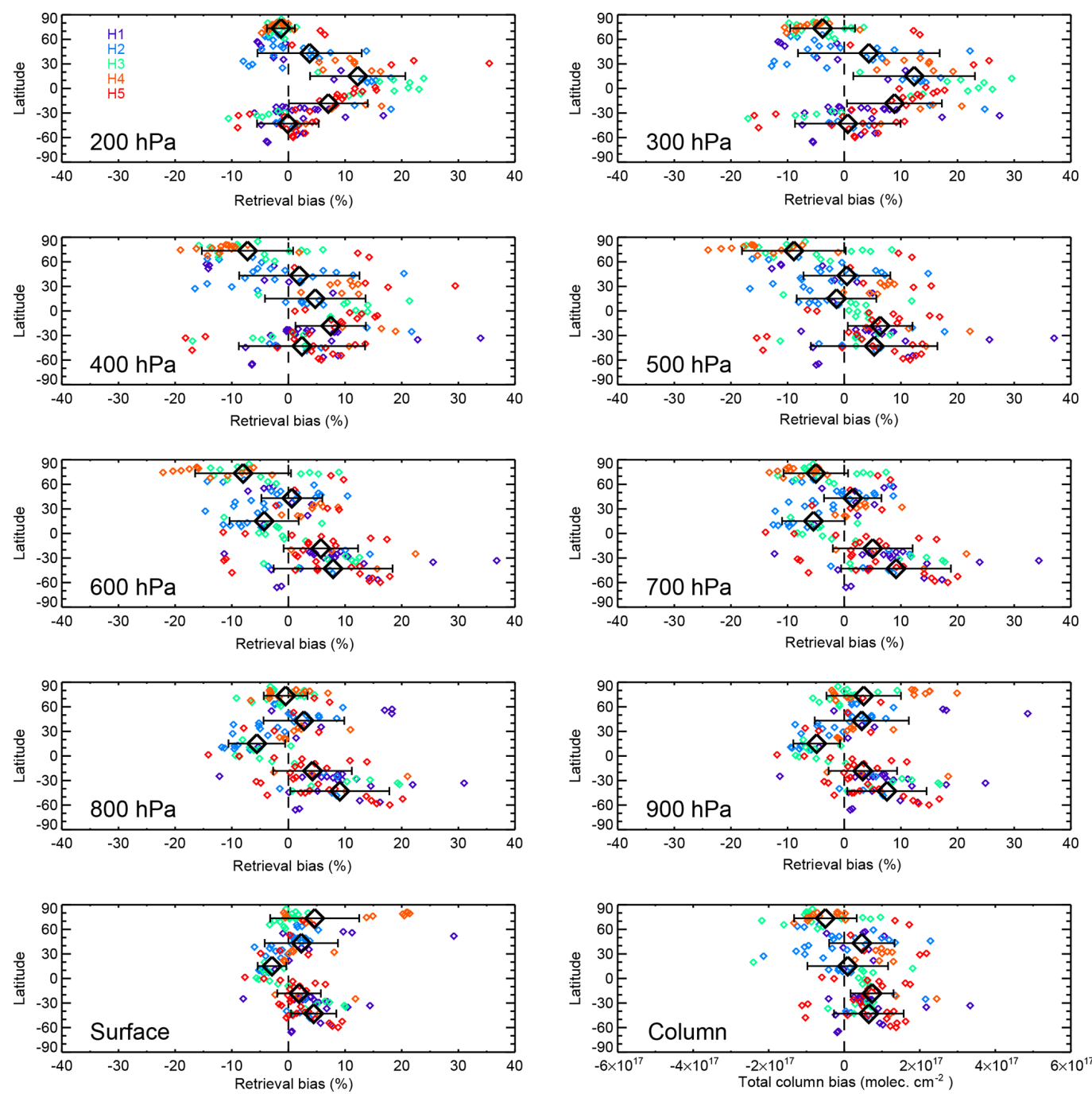

Figure 2. Latitude dependence of V7 TIR-only biases based on the HIPPO CO profiles. Results from each of the five stages of HIPPO are color-coded, as indicated by the key in the top-left panel. Large black diamonds and error bars in each panel indicate bias statistics (mean and standard deviation) representing each $30^{\circ}$ wide latitudinal zone.

biases in the retrieved $\mathrm{CO}$ profiles. Radiance bias correction factors compensate for a variety of potential bias sources including errors in instrumental specifications, forward model errors related to the development of MOPFAS, errors in assumed spectroscopic data, and geophysical errors (Deeter et al., 2014). For previous MOPITT products, radiance bias correction factors were determined empirically by minimizing retrieval biases estimated from validation using aircraft in situ profiles (Deeter et al., 2017). This method resulted in radiance bias correction factors for each of the TIR and NIR radiances used in the MOPITT CO retrieval products. Within the retrieval algorithm, these correction factors are applied by scaling the simulated radiances produced by MOPFAS each time it is executed.

For V8 processing, radiance bias correction is based on a new parameterization involving both (1) the date of the
MOPITT observation and (2) the water vapor total column at the time and geographic location of the MOPITT observation, as derived from the MERRA-2 water vapor profiles needed to execute MOPFAS (Deeter et al., 2017). This strategy is based on the empirical linear dependence of MOPITT retrieval biases on time and water vapor, as shown in Sect. 1. Although the use of this parameterization does not depend on an exact understanding of the physical origin of the biases, it does assume that radiance biases vary linearly with respect to both time and vertically integrated atmospheric water vapor. Within the retrieval software, dynamic radiance bias correction factors for $\mathrm{V} 8$ are therefore calculated using the relation

$R^{i}=R_{0}^{i}+R_{\mathrm{t}}^{i} N_{\mathrm{dys}}+R_{\mathrm{w}}^{i} \mathrm{WV}$,

where $R^{i}$ is the radiance correction factor to be applied to the 

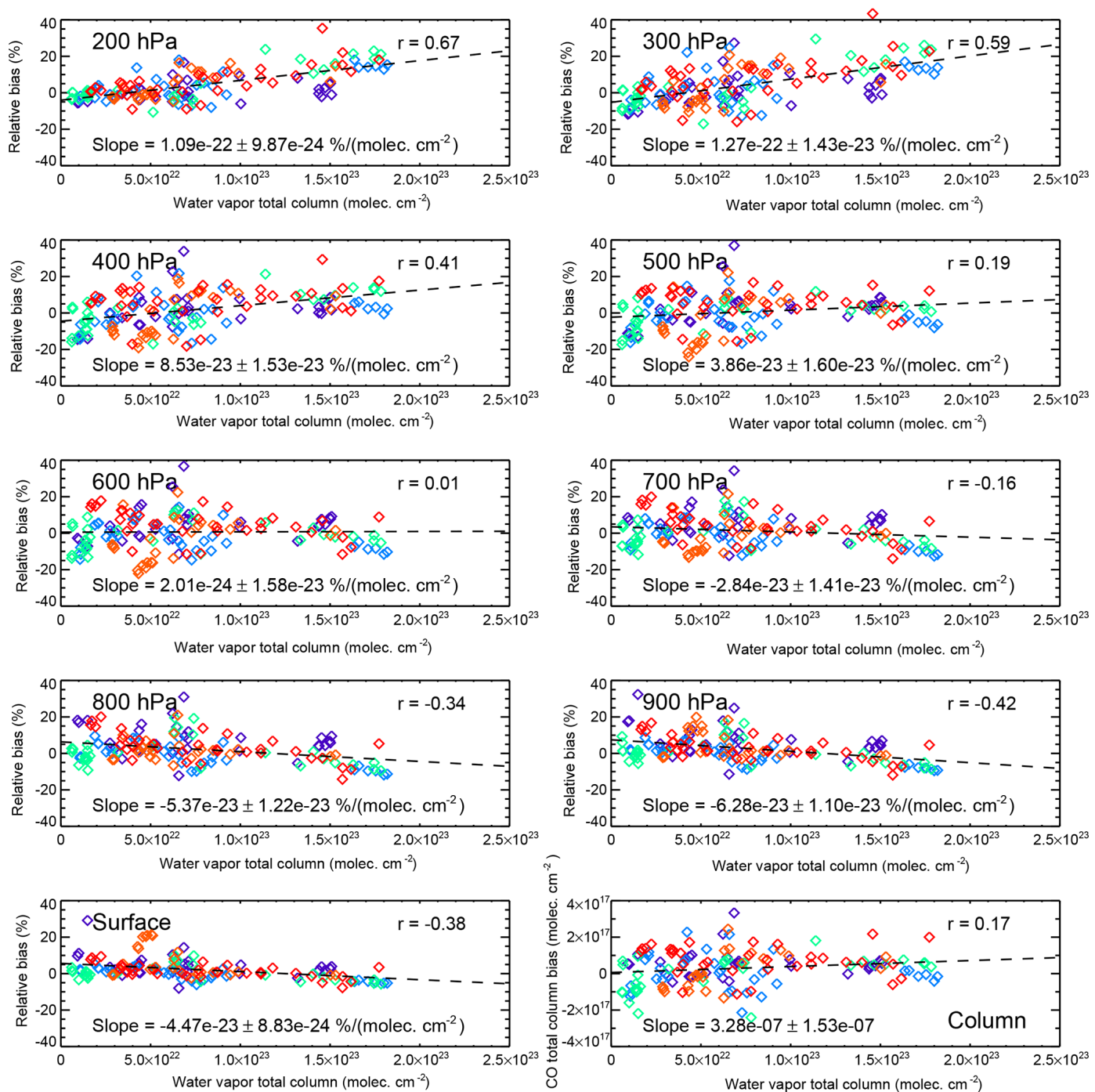

Figure 3. Dependence of V7 TIR-only biases on water vapor total column, based on the HIPPO CO profiles. Colors indicate the particular phase of the HIPPO mission, as described in the caption to Fig. 2.

model-simulated value for radiance $i ; N_{\text {dys }}$ is the number of elapsed days since 1 January 2000; WV is the water vapor total column (or precipitable water vapor, expressed in molec. $\mathrm{cm}^{-2}$ ) determined from the MERRA-2 reanalysis (temporally and spatially interpolated to the time and location of the MOPITT observation); and $R_{0}, R_{\mathrm{t}}$, and $R_{\mathrm{W}}$ are the empirically determined parameters which effectively minimize overall retrieval bias, bias drift, and bias water vapor sensitivity. Values of $R_{0}, R_{\mathrm{t}}$, and $R_{\mathrm{W}}$ for the $5 \mathrm{~A}, 5 \mathrm{D}, 6 \mathrm{D}$, and $7 \mathrm{D}$ radiances used for $\mathrm{V} 8$ operational processing are listed in Table 1. Values of these parameters for the $5 \mathrm{~A}, 5 \mathrm{D}$, and $7 \mathrm{D}$ radiances (i.e., the TIR radiances) were obtained by minimizing retrieval biases for the TIR-only validation results. Values of these parameters for the 6D radiance were obtained by minimizing retrieval biases using NIR-only validation results. Experiments performed to optimize $R_{\mathrm{t}}$ were strictly based on the analysis of bias drift determined using the NOAA profile set; experiments performed to optimize $R_{\mathrm{W}}$ were based solely on the analysis of water-vapordependent biases determined using the HIPPO profile set (described further in Sect. 3). Optimized values of $R_{0}$ were based on both the NOAA and HIPPO results. Nonzero values for the time-dependent term, $R_{\mathrm{t}}$, were found to be necessary only for the 6D and 7D radiances. Nonzero values for $R_{\mathrm{w}}$ were found to be necessary only for the $5 \mathrm{D}$ and $7 \mathrm{D}$ radiances.

\subsection{Averaging kernel calculations}

The averaging kernel matrix A quantifies the sensitivity of the retrieved profile to the true profile and is provided as a diagnostic for each retrieval in all MOPITT products. For users interested in comparisons of MOPITT retrieved CO total column values with other datasets (or model output), the 

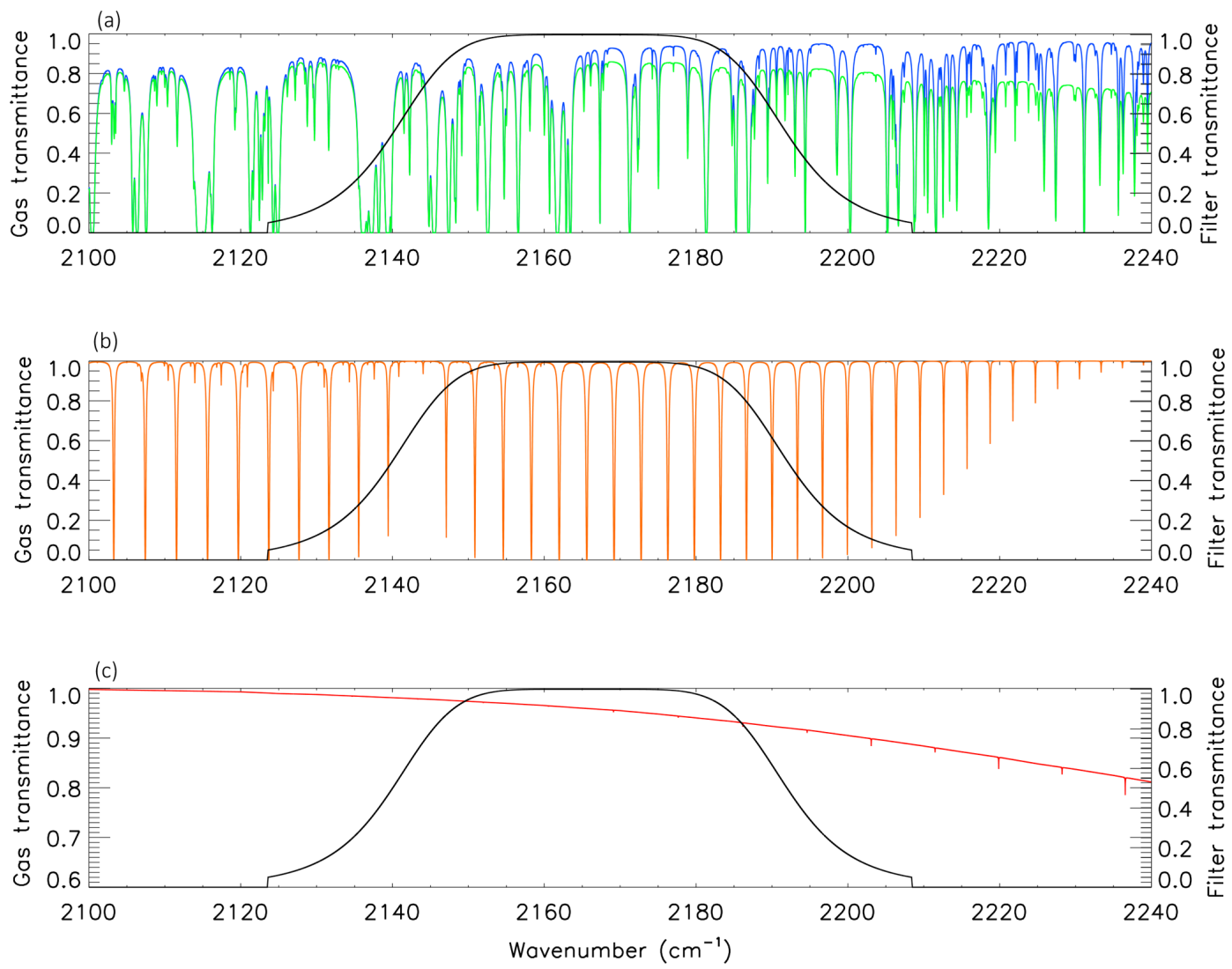

Figure 4. Top-of-atmosphere spectral transmittances for water vapor (a), $\mathrm{CO}$ (b), and nitrogen collisionally induced absorption (c) near the MOPITT TIR passband. Panel (a) compares differences in water vapor absorption calculated with MT_CKD version 1.0 (in blue), used in previous MOPITT forward models, and MT_CKD version 3.2 (in green), used for V8. Panel (c) indicates collisionally induced absorption by nitrogen, which is represented in V8 forward modeling for the first time. The MOPITT TIR passband is indicated in black in all three panels.

Table 1. Radiance bias correction parameters used for processing MOPITT version 8 retrieval products. See Sect. 2 . $R_{0}$ is dimensionless. Units of $R_{\mathrm{t}}$ and $R_{\mathrm{W}}$ are per day $\left(\mathrm{d}^{-1}\right)$ and per molecules per square centimeter $\left(\left(\operatorname{molec} . \mathrm{cm}^{-2}\right)^{-1}\right)$, respectively.

\begin{tabular}{lrrrrr}
\hline & $5 \mathrm{~A}$ & $5 \mathrm{D}$ & $6 \mathrm{~A}$ & $6 \mathrm{D}$ & $7 \mathrm{D}$ \\
\hline$R_{0}$ & 1.05970 & 1.04522 & 1.00000 & 0.99522 & 1.04959 \\
$R_{\mathrm{t}}$ & 0.0 & 0.0 & 0.0 & $9.6 \times 10^{-7}$ & $-1.18 \times 10^{-5}$ \\
$R_{\mathrm{W}}$ & 0.0 & $-8.09 \times 10^{-27}$ & 0.0 & 0.0 & $-6.00 \times 10^{-25}$ \\
\hline
\end{tabular}

V8 Level 2 product files also include the total column averaging kernel $\boldsymbol{a}$. The vector $\boldsymbol{a}$ quantifies the sensitivity of the retrieved total column to perturbations at each level of the $\mathrm{CO}$ profile, as described in the MOPITT User's Guide (MOPITT Algorithm Development Team, 2018). If $C_{\mathrm{rtv}}$ is the retrieved CO total column, and $\boldsymbol{x}$ is the state vector comprised of actual CO $\log (\mathrm{VMR})$ values, the total column averaging kernel element for profile level $j$ is defined by

$\boldsymbol{a}_{j}=\partial C_{\mathrm{rtv}} / \partial \boldsymbol{x}_{j}$

Given a comparison CO profile $\boldsymbol{x}_{\mathrm{cmp}}$ (typically either from in situ measurements or model output), the total column av- eraging kernel vector may be used to simulate MOPITT total column retrievals using the equation

$C_{\mathrm{sim}}=C_{\mathrm{a}}+\boldsymbol{a}\left(\boldsymbol{x}_{\mathrm{cmp}}-\boldsymbol{x}_{\mathrm{a}}\right)$,

where $C_{\mathrm{a}}$ is the a priori total column value corresponding to the a priori profile $\boldsymbol{x}_{\mathrm{a}}$. (Both $C_{\mathrm{a}}$ and $\boldsymbol{x}_{\mathrm{a}}$ are provided for each retrieval in the V8 Level 2 product files.)

For V8, the method of calculating $\boldsymbol{a}$ has been revised for consistency with the method of Rodgers (2000) (Sect. 4.3). Specifically, the total column averaging kernel is now calculated as

$\boldsymbol{a}^{\mathrm{T}}=\boldsymbol{h}^{\mathrm{T}} \mathbf{A}$, 

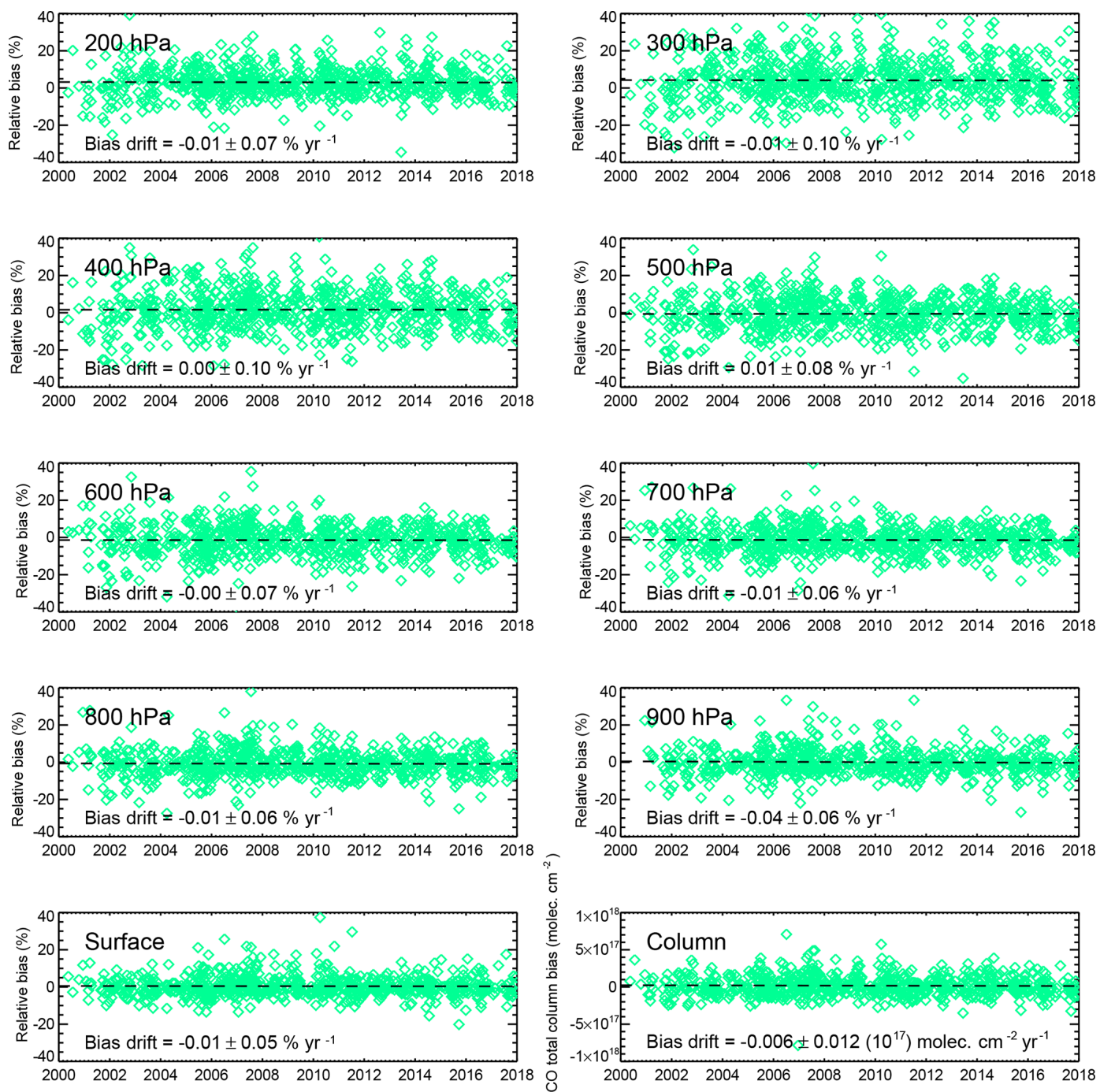

Figure 5. Retrieval bias drift for V8 TIR-only products based on the NOAA flask measurements.

where $\boldsymbol{h}$ is the partial column operator (i.e., the vector of derivatives of $\mathrm{CO}$ partial column values with respect to perturbations in $\log (\mathrm{VMR})$, referenced to the retrieved profile) and $\mathbf{A}$ is the full averaging kernel matrix. The vector $\boldsymbol{h}$ is calculated internally in the MOPITT retrieval code. While the new method for calculating $\boldsymbol{a}$ is more rigorous than the previously used method, resulting differences in total column validation statistics (correlation coefficient, bias, and standard deviation) were found to be insignificant. In addition, a software coding error has been corrected which, for V7 products, resulted in erroneous values of $\boldsymbol{a}$ for retrieved profiles with less than 10 valid levels (i.e., surface pressures less than $900 \mathrm{hPa})$.

\subsection{Cloud detection}

The MOPITT retrieval algorithm generally discards MOPITT observations in which clouds are detected. The cloud detection algorithm used for this purpose makes use of both the MOPITT radiances and the MODIS cloud mask (Francis et al., 2017). The MOPITT channel 7 average radiance is employed for cloud detection since it is relatively less sensitive to $\mathrm{CO}$ variability than the other MOPITT TIR radiances. For V8, two changes have been made with respect to cloud detection. First, V8 products for the entire MOPITT mission are produced using MODIS Collection 6.1 cloud mask files. (Differences between Collection 6 and Collection 6.1 MODIS cloud products are documented in Moeller and Frey, 2017). Second, due to changes in the radiative transfer model described in Sect. 2.1, the threshold ratio value used to test the MOPITT channel 7 average radiance for cloudiness (relative to the MOPFAS-based first-guess value) was increased 

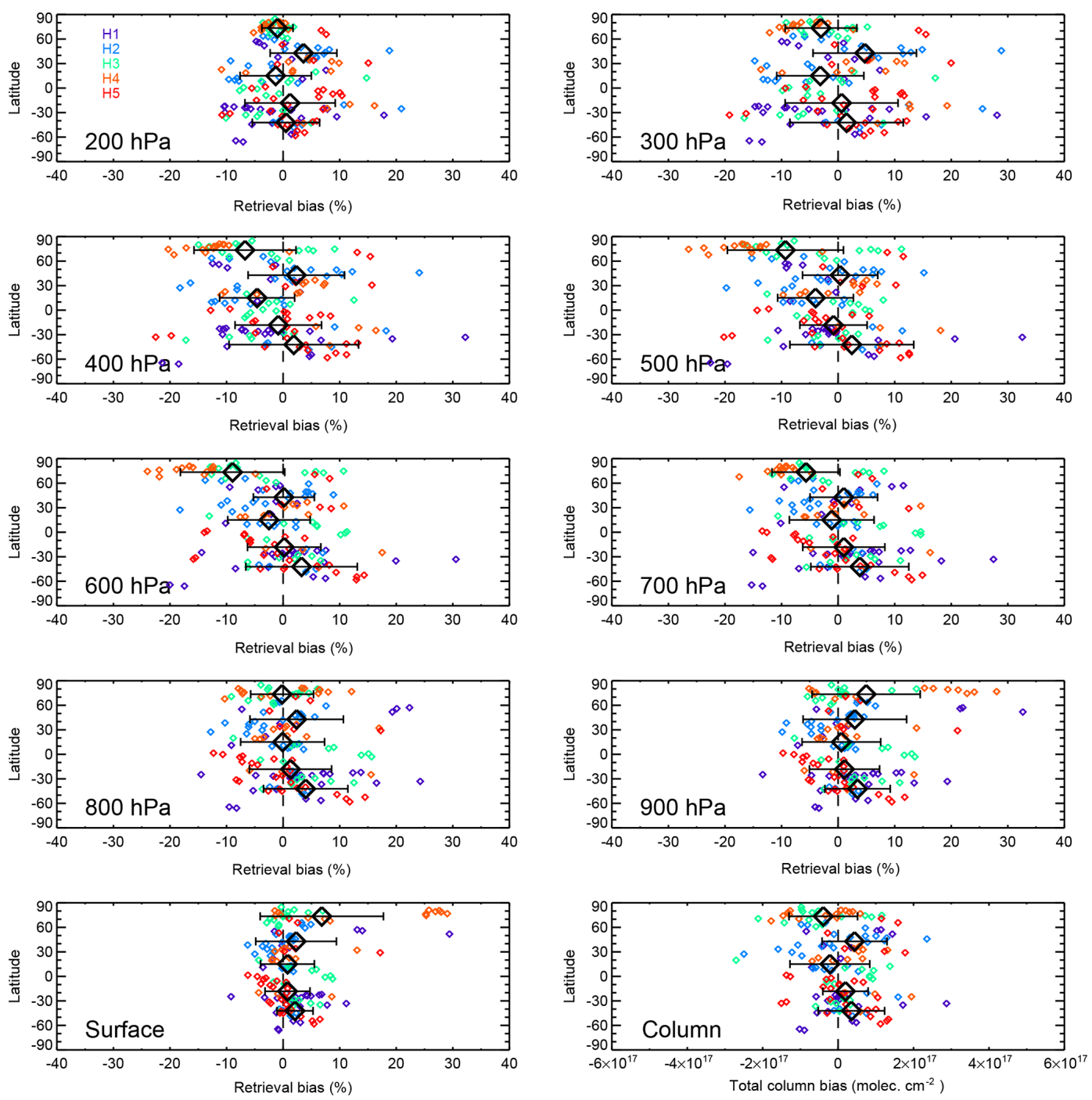

Figure 6. Latitude dependence of V8 TIR-only biases (expressed in percent) based on the HIPPO CO profiles. See caption to Fig. 2.

from 0.955 to 1.000 . This value was selected to achieve consistent rates of clear-sky determinations for V7 and V8 processing; hence, any observed differences between V7 and V8 products are unlikely to be related to cloud detection.

\section{Validation}

Below, retrieval validation results are reported separately for V8 TIR-only, NIR-only, and TIR-NIR products. Validation results are based on statistical comparisons of MOPITT retrieval products ( $\mathrm{CO}$ volume mixing ratio profiles and total columns) with in situ vertical profiles measured from aircraft. For this purpose, in situ measurements are assumed to be exact and representative of an extended region around the sampling location. Other remote sensing datasets, such as the TCCON (Total Carbon Column Observing Network) and NDACC (Network for the Detection of Atmospheric Com- position Change) datasets, are potentially useful for MOPITT validation (Buchholz et al., 2017); however, results are more difficult to analyze due to differences in retrieval averaging kernels and a priori CO concentrations (Rodgers, 2003). Thus, results presented in this paper are solely based on aircraft in situ profiles whereby averaging kernel effects are taken fully into account.

Because of the coarse vertical resolution of the radiance weighting functions (or Jacobians) and the underconstrained nature of the retrieval process, retrieval products obtained with optimal-estimation-based algorithms are constrained by a priori information as well as the measurements (Pan et al., 1998; Rodgers, 2000). A priori information is represented by (1) an a priori profile $\boldsymbol{x}_{\mathrm{a}}$ and (2) an a priori covariance matrix, which defines the strength of the a priori constraint. The relationship between the true profile $\boldsymbol{x}_{\text {true }}, \boldsymbol{x}_{\mathrm{a}}$, and retrieved 

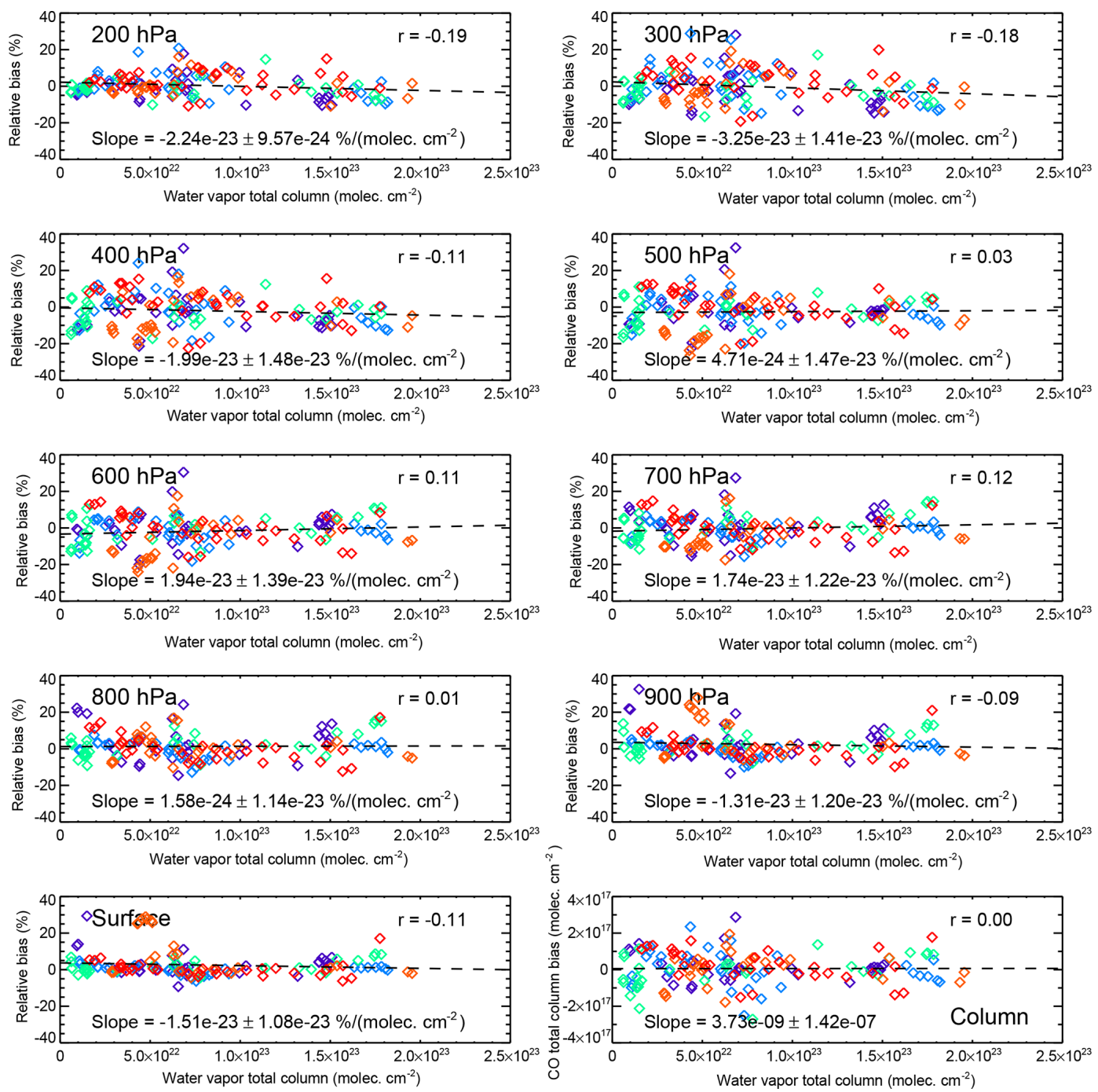

Figure 7. Dependence of V8 TIR-only biases on water vapor total column, based on the HIPPO CO profiles. Colors indicate the particular phase of the HIPPO mission, as described in the caption to Fig. 2.

profile $\boldsymbol{x}_{\mathrm{rtv}}$ is expressed by the equation

$\boldsymbol{x}_{\mathrm{rtv}}=\boldsymbol{x}_{\mathrm{a}}+\mathbf{A}\left(\boldsymbol{x}_{\text {true }}-\boldsymbol{x}_{\mathrm{a}}\right)$,

where $\mathbf{A}$ is the retrieval averaging kernel matrix. The vector quantities $\boldsymbol{x}_{\text {true }}, \boldsymbol{x}_{\mathrm{a}}$, and $\boldsymbol{x}_{\mathrm{rtv}}$ are expressed in terms of $\log (\mathrm{VMR})$ rather than VMR itself.

\subsection{Validation datasets}

V8 validation results reported below exploit a large set of $\mathrm{CO}$ vertical profiles measured by the NOAA Global Monitoring Division using an airborne flask-sampling system followed by laboratory analysis (Sweeney et al., 2015). Typical profiles are derived from a set of 12 flasks. Reproducibility of the laboratory-measured $\mathrm{CO}$ dry-air mole fractions, which are measured by either a vacuum UV-resonance fluorescence spectrometer or a reduction gas analyzer, is better than $1 \mathrm{ppb}$.
This set is composed of profiles obtained during flights at 21 fixed sites (mainly over North America) between 2000 and 2018. The consistency and high accuracy characterizing this set of profiles is the primary basis for quantifying longterm changes in MOPITT retrieval biases (Deeter et al., 2003, 2017).

$\mathrm{CO}$ vertical profiles acquired from aircraft-based instruments during field campaigns complement the NOAA set of profiles. Pertinent characteristics of these datasets (and the NOAA dataset) are listed in Table 2. The HIPPO field campaign was conducted in five phases between 2009 and 2011 (Wofsy et al., 2011) and has been especially useful for MOPITT validation (Deeter et al., 2014, 2017). Flights for HIPPO were conducted during January 2009 (Phase 1), November 2009 (Phase 2), April 2010 (Phase 3), June 2011 (Phase 4), and August-September 2011 (Phase 5). Because of the wide range of latitudes represented, this set of $\mathrm{CO}$ ver- 
Table 2. Characteristics of CO in situ datasets used for algorithm development (bias minimization) and retrieval validation. See Sect. 3.1. Number of profiles refers only to aircraft-based profiles which were successfully collocated with MOPITT retrievals.

\begin{tabular}{lllrll}
\hline & Observational period & Region & $N$ profiles & Technique & Primary Use \\
\hline NOAA & $2000-2018$ & N. America & 1339 & Flask samples & Bias min. \\
HIPPO & $2009-2011$ & Pacific Ocean & 358 & QCLS & Bias min. \\
ACRIDICON-CHUVA & 2014 & Amazonia & 18 & VUV res. fluor. & Validation \\
KORUS-AQ & 2016 & S. Korea & 42 & DACOM & Validation \\
ATom & $2016-2017$ & Pacific and Atlantic oceans & 254 & QCLS & Validation \\
\hline
\end{tabular}

tical profiles is useful for investigating geographically variable retrieval biases.

Validation results are also reported below for several more recent field campaigns, including (1) ACRIDICON-CHUVA (Aerosol, Cloud, Precipitation, and Radiation Interactions and Dynamics of Convective Cloud Systems - Cloud processes of the main precipitation systems in Brazil: A contribution to cloud resolving modeling and to the GPM (Global Precipitation Measurement)) (Wendisch et al., 2016), hereafter referred to as "AC"; (2) KORUS-AQ (The Korea-United States Air Quality Study, https://espo.nasa.gov/korus-aq/ content/KORUS-AQ_White_Paper, last access: 14 August 2019); and (3) ATom (The Atmospheric Tomography Mission, https://espo.nasa.gov/atom/content/ATom, last access: 14 August 2019). CO measurements from AC were previously used to validate the MOPITT V6 product (Deeter et al., 2016); however, CO datasets from KORUS-AQ and ATom are used here for MOPITT validation for the first time. AC was conducted in September 2014, while the KORUS-AQ campaign was conducted from April to June 2016. For the ongoing ATom campaign, results are presented for phases 1 and 2, conducted in July and August 2016 and January and February 2017, respectively. CO measurements for AC were performed using an Aero-Laser 5002 vacuum UV resonance fluorescence instrument (Wendisch et al., 2016), CO measurements for KORUS-AQ were performed with the DACOM (Differential Absorption Carbon monOxide Measurement) instrument (Sachse et al., 1987), and CO measurements for both HIPPO and ATom were performed with the QCLS (quantum cascade laser spectrometer) instrument (Santoni et al., 2014).

For matching MOPITT retrieved profiles with in situ profiles, a maximum collocation radius of $50 \mathrm{~km}$ was employed for the NOAA and KORUS-AQ profiles, whereas a value of $200 \mathrm{~km}$ was used for the HIPPO, AC, and ATom profiles. The smaller radius for NOAA and KORUS-AQ was chosen to reduce validation errors resulting from large horizontal $\mathrm{CO}$ gradients associated with urban emissions from North America and Korea. For all in situ datasets, a maximum of $12 \mathrm{~h}$ was allowed between the time of the MOPITT observation and sampling time of the in situ data. Maximum altitudes for individual profiles varied in the datasets from approximately 7 to $14 \mathrm{~km}$. In order to obtain a complete validation profile for comparison with MOPITT retrievals, each in situ profile was extended vertically above the highest-altitude in situ measurement using the CAM-chem (Community Atmosphere Model with Chemistry) chemical transport model (Lamarque et al., 2012) and then resampled to the standard pressure grid used for the MOPITT operational radiative transfer model (Martínez-Alonso et al., 2014). Validation results for the MOPITT $100 \mathrm{hPa}$ retrieval level are not reported below, since apparent retrieval errors due to reliance on the modelbased extension at the top of the profile are much greater than for lower retrieval levels. Reliable validation of the MOPITT $100 \mathrm{hPa}$ retrieval level will require in situ profiles that reach higher altitudes than are currently available.

V8 validation results are separately reported below for two groups of in situ profiles. Validation results for the NOAA and HIPPO datasets, representing the first class of profiles, indicate the success of the retrieval bias minimization method described in Sect. 2, which was specifically optimized to minimize retrieval biases for these two datasets. In addition, validation results are presented for in situ profiles acquired during the three campaigns (AC, KORUS-AQ, and ATom) which were not exploited in the development of the bias minimization method. The results for this second class of profiles provide a completely independent evaluation of the MOPITT retrieval biases.

\subsection{TIR-only}

Validation results derived from the NOAA aircraft flask samples for the V8 TIR-only products are presented as a retrieval bias time series plot in Fig. 5. Corresponding results for the V7 TIR-only products were shown in Fig. 1. Each panel in the figure corresponds to a particular MOPITT retrieval level. (Results are not shown for the $100 \mathrm{hPa}$ retrieval level, since the corresponding layer is generally not well measured in the aircraft in situ datasets.) Retrieval biases for individual overpasses are quantified as relative deviations (expressed in percent) between the mean retrieved $\log (\mathrm{VMR})$ value and the corresponding value calculated using the in situ profile data, a priori profile, and MOPITT averaging kernel matrix (Deeter et al., 2017). Validation statistics for total column and alternating retrievals levels, including relative bias, standard deviation, and correlation coefficient, are also summarized and compared with statistics for $\mathrm{V} 7$ products in Table 3 . 
Table 3. Summarized validation results for V7 and V8 TIR-only (V7T and V8T), NIR-only (V7N and V8N), and TIR-NIR (V7J and V8J) products based on in situ data from NOAA aircraft validation sites. Bias and standard deviation (SD) statistics for the total column are in units of $10^{17}$ molec. $\mathrm{cm}^{-2}$. Bias and SD for retrieval levels are expressed in percent $(\%)$. Total column drift values are provided in units of both $10^{17}$ molec. $\mathrm{cm}^{-2} \mathrm{yr}^{-1}$ and percent per year $\left(\% \mathrm{yr}^{-1}\right.$, in parentheses). Drift for the retrieval levels is expressed in percent per year $\left(\% \mathrm{yr}^{-1}\right)$.

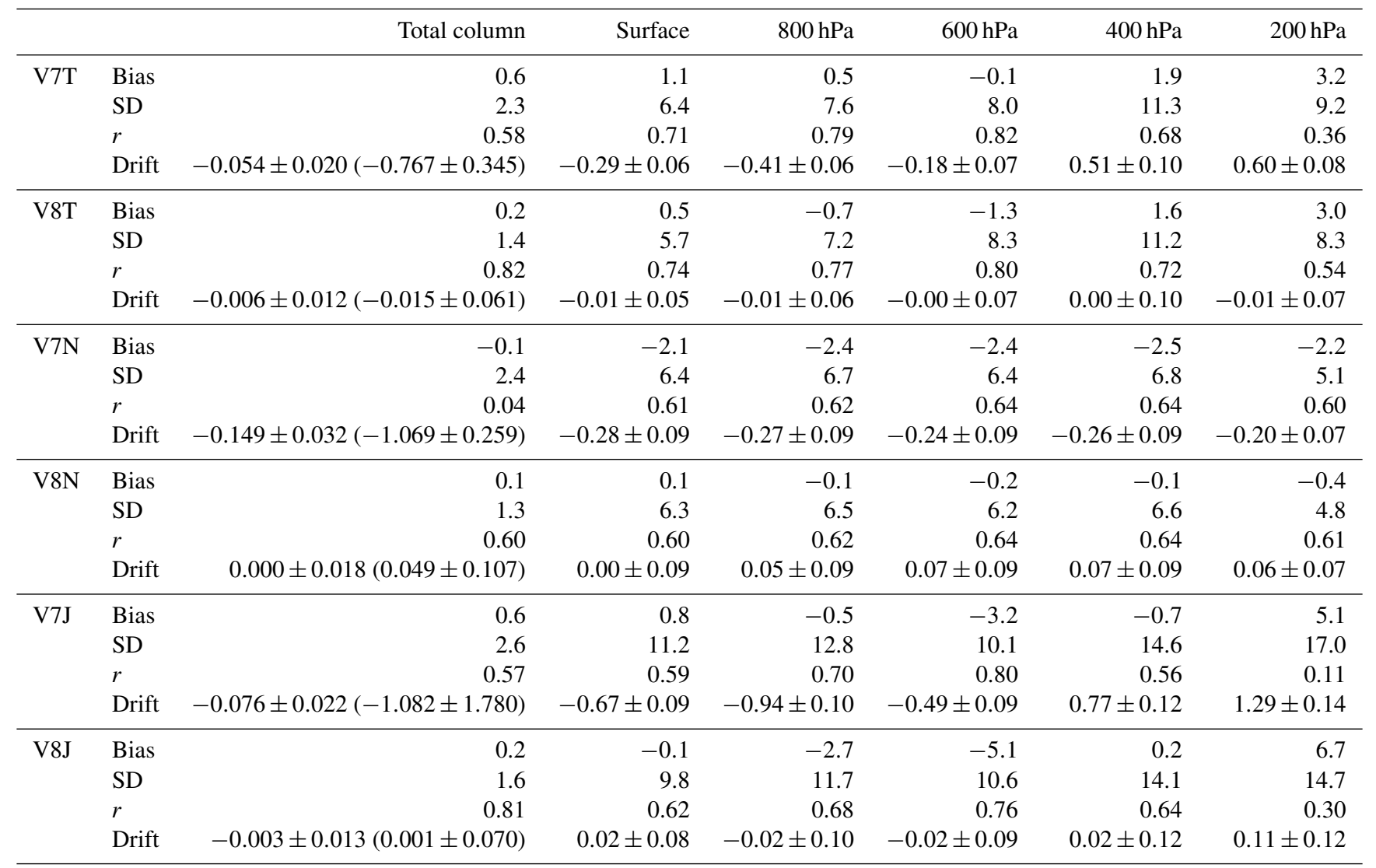

Correlations due simply to the variability of the a priori $\mathrm{CO}$ concentrations are avoided by basing correlation coefficient calculations on $\left(\boldsymbol{x}_{\mathrm{rtv}}-\boldsymbol{x}_{\mathrm{a}}\right)$ rather than $x_{\mathrm{rtv}}$.

Overall biases for V8 TIR-only products for the NOAA profile set (averaged over all validation sites and over the whole mission) vary from $-1.3 \%$ to $3.0 \%$. These small values are roughly similar to values for the V7 TIR-only product. Bias drift, however, is significantly improved for V8. Bias drift is calculated as the slope of a least-squares best fit applied to the time series data presented in Fig. 5 and converted from units of $\Delta \log (\mathrm{VMR}) \mathrm{yr}^{-1}$ to percent per year $\left(\% \mathrm{yr}^{-1}\right)$ as described in Deeter et al. (2017). For each retrieval level depicted in Fig. 5, the best-fit slope of the time series is within the uncertainty of the slope derived from the least-squares fit, which is generally less than $0.1 \% \mathrm{yr}^{-1}$ at all retrieval levels. These results demonstrate that retrieval bias drift has been effectively eliminated in V8 TIR-only products at all retrieval levels, at least over North America. The lack of long-term $\mathrm{CO}$ aircraft-based datasets for other regions prevents general conclusions regarding the geographical variability of bias drift in V8 products.
V8 TIR-only biases derived from HIPPO validation results are plotted versus latitude in Fig. 6 and against water vapor total column in Fig. 7. Bin-averaged latitude-dependent biases for V8T are compared with V7T results in Table 4. Clear improvements are apparent in comparison with the V7 results presented in Figs. 2 and 3, in both the upper and lower troposphere. For example, at $300 \mathrm{hPa}$, bin-averaged latitudedependent biases for V7T vary from about $-4 \%$ to $12 \%$, in comparison to $-3 \%$ to $5 \%$ for V8T. This improvement is consistent with the weaker dependence of biases on water vapor, as indicated by comparing Figs. 3 and 7. At $300 \mathrm{hPa}$, the bias water vapor dependence (determined again by a leastsquares fit) decreases from $1.27 \times 10^{-22} \%\left(\text { molec. } \mathrm{cm}^{-2}\right)^{-1}$ for V7T to $3.25 \times 10^{-23} \%$ (molec. $\left.\mathrm{cm}^{-2}\right)^{-1}$ for V8T. Significant improvements are also apparent in Figs. 6 and 7 in the lower troposphere, e.g., at $800 \mathrm{hPa}$.

V8 TIR-only biases as determined from validation results for the AC, KORUS-AQ, and ATom campaigns are plotted versus latitude in Fig. 8. Validation statistics for the individual campaigns are also listed in Table 5. With a few exceptions, the V8T latitudinally bin averaged retrieval biases for 
Table 4. Latitude dependence of validation results for V7 and V8 TIR-only products as indicated using in situ data from the HIPPO field campaign and corresponding to results shown in Figs. 2 and 6. See caption to Table 2.

\begin{tabular}{|c|c|c|c|c|c|c|c|c|}
\hline & & & Total column & Surface & $800 \mathrm{hPa}$ & $600 \mathrm{hPa}$ & $400 \mathrm{hPa}$ & $200 \mathrm{hPa}$ \\
\hline \multirow[t]{10}{*}{ V7T } & \multirow[t]{2}{*}{$60 \mathrm{~N}: 90 \mathrm{~N}$} & Bias & -0.50 & 4.6 & -0.5 & -8.0 & -7.2 & -1.3 \\
\hline & & SD & 0.83 & 7.9 & 3.9 & 8.5 & 8.1 & 2.5 \\
\hline & \multirow[t]{2}{*}{$30 \mathrm{~N}: 60 \mathrm{~N}$} & Bias & 0.47 & 2.3 & 2.7 & 0.6 & 1.9 & 3.7 \\
\hline & & SD & 0.87 & 6.5 & 7.1 & 5.4 & 10.6 & 9.2 \\
\hline & \multirow[t]{2}{*}{$\mathrm{Eq}: 30 \mathrm{~N}$} & Bias & 0.09 & -2.9 & -5.6 & -4.3 & 4.7 & 12.2 \\
\hline & & SD & 1.07 & 2.5 & 5.0 & 6.1 & 8.9 & 8.4 \\
\hline & \multirow[t]{2}{*}{ 30S:Eq } & Bias & 0.74 & 1.9 & 4.3 & 5.7 & 7.5 & 7.0 \\
\hline & & SD & 0.57 & 3.8 & 6.9 & 6.6 & 6.2 & 7.0 \\
\hline & \multirow[t]{2}{*}{$60 \mathrm{~S}: 30 \mathrm{~S}$} & Bias & 0.65 & 4.5 & 9.1 & 7.9 & 2.4 & -0.1 \\
\hline & & SD & 0.92 & 4.0 & 8.7 & 10.5 & 11.1 & 5.4 \\
\hline \multirow[t]{10}{*}{ V8T } & \multirow[t]{2}{*}{$60 \mathrm{~N}: 90 \mathrm{~N}$} & Bias & -0.39 & 6.8 & -0.2 & -8.9 & -6.7 & -1.0 \\
\hline & & SD & 0.91 & 10.9 & 5.6 & 9.2 & 9.0 & 2.8 \\
\hline & \multirow[t]{2}{*}{$30 \mathrm{~N}: 60 \mathrm{~N}$} & Bias & 0.44 & 2.3 & 2.4 & 0.1 & 2.3 & 3.6 \\
\hline & & SD & 0.86 & 7.1 & 8.3 & 5.4 & 8.5 & 5.9 \\
\hline & \multirow[t]{2}{*}{ Eq:30N } & Bias & -0.22 & 0.8 & -0.1 & -2.5 & -4.6 & -1.3 \\
\hline & & SD & 1.06 & 4.8 & 7.4 & 7.3 & 6.6 & 6.3 \\
\hline & \multirow[t]{2}{*}{ 30S:Eq } & Bias & 0.20 & 0.8 & 1.3 & 0.2 & -0.9 & 1.2 \\
\hline & & SD & 0.60 & 4.0 & 7.3 & 6.5 & 7.6 & 8.0 \\
\hline & \multirow[t]{2}{*}{$60 S: 30 S$} & Bias & 0.35 & 2.1 & 4.0 & 3.3 & 1.9 & 0.5 \\
\hline & & SD & 0.88 & 3.2 & 7.5 & 9.9 & 11.5 & 6.0 \\
\hline
\end{tabular}

Table 5. Summarized validation results for V8 products based on in situ data from ACRIDICON-CHUVA, KORUS-AQ, and ATom field campaigns. See caption to Table 2.

\begin{tabular}{ccccccccc}
\hline & & & Total column & Surface & $800 \mathrm{hPa}$ & $600 \mathrm{hPa}$ & $400 \mathrm{hPa}$ & $200 \mathrm{hPa}$ \\
\hline ACRIDICON & V8T & Bias & 0.8 & 1.9 & 2.9 & 3.6 & 5.3 & 6.6 \\
& & SD & 1.5 & 4.6 & 7.0 & 7.3 & 7.2 & 6.3 \\
& & $r$ & 0.79 & 0.82 & 0.82 & 0.77 & 0.75 & 0.80 \\
\hline & V8N & Bias & 1.3 & 4.5 & 4.6 & 3.9 & 3.9 & 3.3 \\
& & SD & 0.9 & 3.1 & 3.2 & 3.0 & 3.2 & 2.8 \\
& & $r$ & 0.82 & 0.83 & 0.83 & 0.81 & 0.80 & 0.80 \\
\hline \multirow{6}{*}{ KORUS-AQ } & V8J & Bias & 0.7 & 4.5 & 1.2 & 0.5 & 1.8 & 10.4 \\
& & SD & 1.6 & 5.8 & 8.9 & 9.7 & 9.3 & 8.2 \\
& & $r$ & 0.80 & 0.88 & 0.82 & 0.65 & 0.65 & 0.87 \\
\hline & Bias & 0.0 & -0.8 & -2.9 & -2.5 & 2.0 & 4.2 \\
& & SD & 1.1 & 4.5 & 4.5 & 5.4 & 7.5 & 5.5 \\
& V8N & Bias & 0.91 & 0.84 & 0.90 & 0.86 & 0.79 & 0.73 \\
\hline & SD & 1.0 & 4.3 & 3.6 & 3.0 & 3.0 & 2.0 \\
& & $r$ & 0.67 & 0.69 & 0.66 & 0.64 & 0.64 & 0.66 \\
\hline ATom & V8J & Bias & 0.1 & -1.5 & -6.6 & -7.5 & 0.8 & 11.2 \\
& & SD & 1.3 & 7.5 & 6.0 & 6.3 & 10.0 & 10.3 \\
& & $r$ & 0.89 & 0.77 & 0.83 & 0.81 & 0.77 & 0.68 \\
\hline & V8T & Bias & 0.2 & 0.8 & 0.8 & 0.4 & 1.2 & 1.9 \\
& & SD & 1.5 & 5.0 & 7.9 & 9.4 & 9.8 & 5.8 \\
& & & 0.70 & 0.47 & 0.67 & 0.77 & 0.81 & 0.77 \\
\hline
\end{tabular}



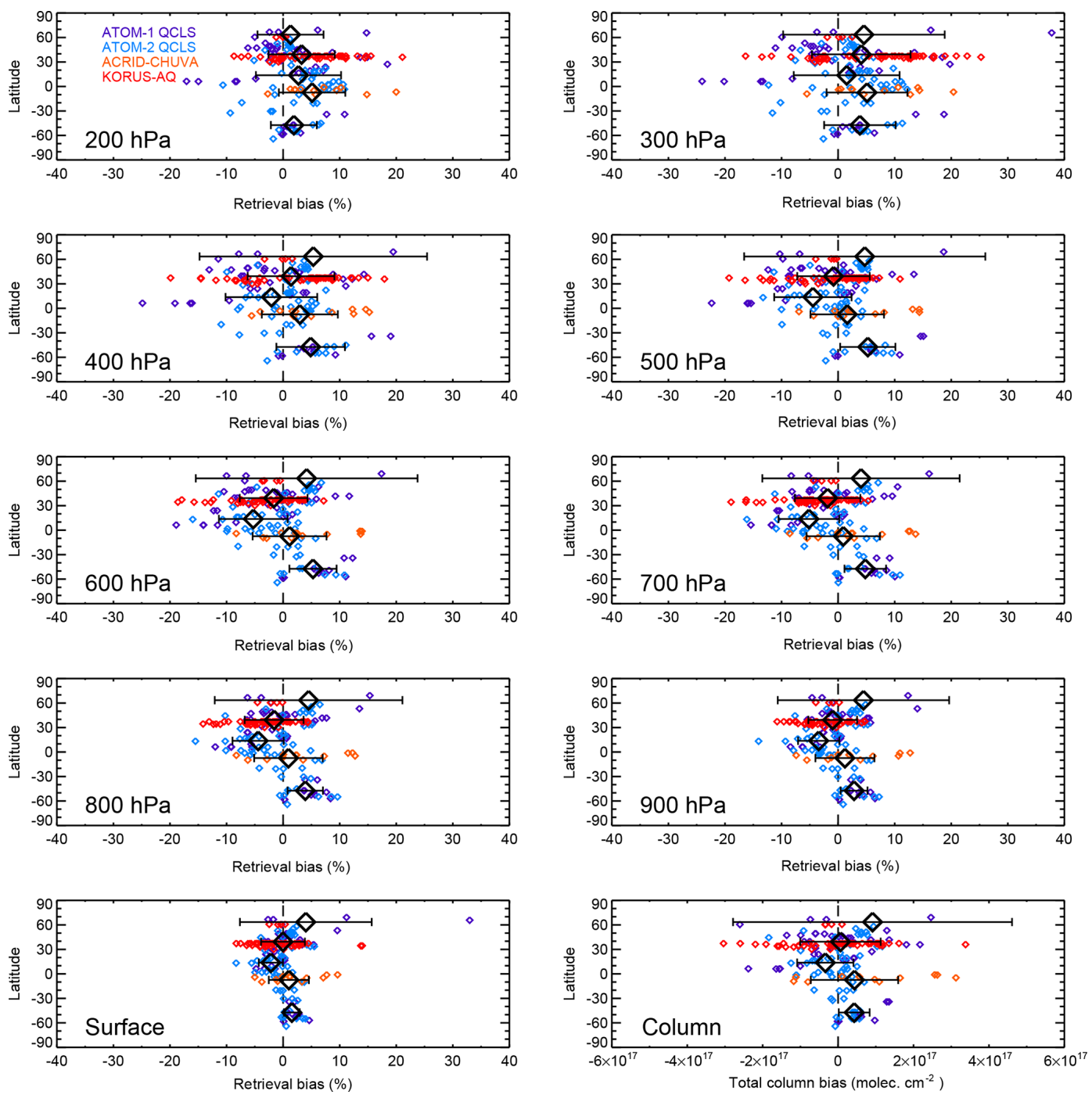

Figure 8. V8 TIR-only biases based on the ATom (phases 1 and 2), ACRIDICON, and KORUS-AQ CO profiles. Results are color-coded as indicated by the key in the top-left panel.

both the HIPPO validation results in Fig. 6 and for the three other campaigns in Fig. 8 are generally within $\pm 5 \%$ at all retrieval levels. Biases outside of this range are most evident between 60 and $90^{\circ} \mathrm{N}$. However, this could be related to the sparseness of profiles in this region and the influence of a small number of outliers.

\subsection{NIR-only}

A time series plot for V8 NIR-only retrieval biases based on the NOAA profile set is presented in Fig. 9. Statistics are also summarized and compared with V7 validation statistics in Table 3. Whereas mean V7N biases for the NOAA profile set exceeded $2 \%$, overall biases for V8N are less than $1 \%$. With respect to long-term stability, NIR-only bias drift has been reduced from about $-0.3 \% \mathrm{yr}^{-1}$ to less than $0.1 \% \mathrm{yr}^{-1}$ at all levels, which again is comparable to the bias drift statis- tical uncertainty. MOPITT NIR-only retrievals are only produced for daytime observations over land. Thus, since the HIPPO campaign was primarily conducted over the Pacific Ocean, profiles from that campaign are not useful for validating MOPITT NIR-only retrievals. V8N retrieval biases for the AC and KORUS-AQ campaigns are, however, plotted versus latitude in Fig. 10; corresponding statistics are also summarized in Table 5. V8N biases based on the KORUSAQ profiles are close to $1 \%$, which is consistent with the NOAA profile results, whereas biases for the AC campaign are close to $5 \%$. For V8N products, the lack of aircraft profiles over land for regions other than North America, South Korea, and the Amazon basin prevents a full analysis of retrieval bias geographical variability. 

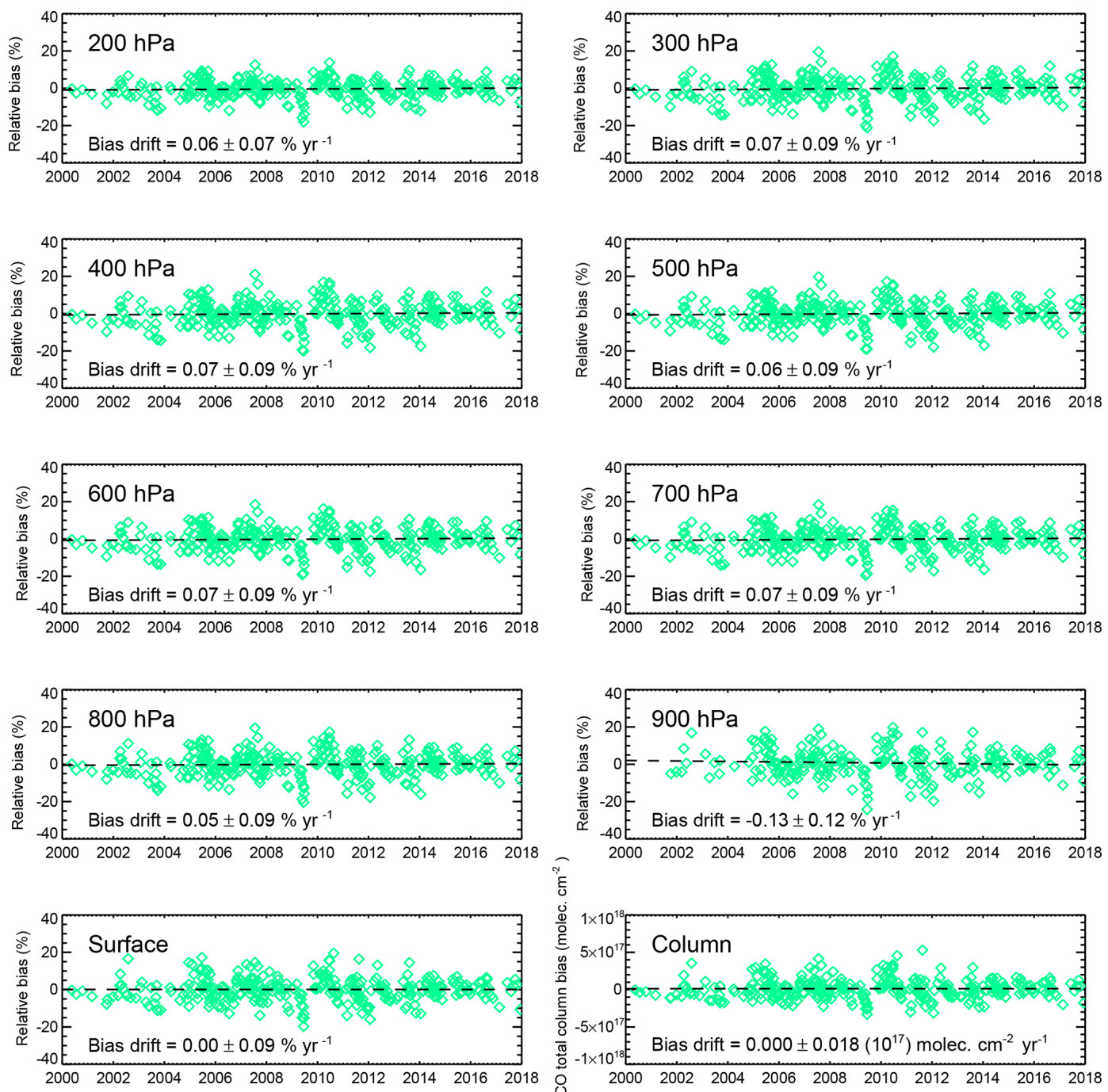

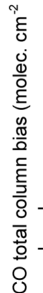

Figure 9. Retrieval bias drift for V8 NIR-only products based on the NOAA flask measurements.

\subsection{TIR-NIR}

V8 TIR-NIR retrieval biases based on the NOAA profiles are presented as time series plots in Fig. 11, with summary statistics compared to statistics for V7 in Table 3. As indicated in that Table and in various figures, retrieval biases and standard deviations tend to be larger for both the V7 and V8 TIR-NIR products compared to the corresponding TIR-only products. This effect results from the strategy to amplify the weight assigned to the NIR measurements in the NIR-only and TIR-NIR products (Deeter et al., 2012). Overall biases for V8, which vary from about $-5 \%$ at $600 \mathrm{hPa}$ to about $7 \%$ at $200 \mathrm{hPa}$, are slightly larger than for V7. Bias drift, however, which exhibits large values for both the lower and upper troposphere for $\mathrm{V} 7$ products (e.g., $0.94 \% \mathrm{yr}^{-1}$ at $800 \mathrm{hPa}$ and $1.29 \% \mathrm{yr}^{-1}$ at $200 \mathrm{hPa}$ ), has been decreased to statistically negligible values $\left(0.1 \% \mathrm{yr}^{-1}\right.$ or less $)$ at all retrieval levels for V8. V8 TIR-NIR retrieval biases for the AC,
KORUS-AQ, and ATom campaigns are plotted versus latitude in Fig. 12. Results shown in Fig. 12 represent both land scenes (where both TIR and NIR radiances are exploited) and ocean scenes (where retrievals are based only on TIR radiances). Summary statistics for the AC and KORUS-AQ campaigns are also listed in Table 5. V8 TIR-NIR biases for the AC and KORUS-AQ campaigns are generally consistent with the corresponding NOAA results (within $5 \%$ at all levels).

\section{Conclusions}

Approaching a length of two decades, the MOPITT record for tropospheric $\mathrm{CO}$ is uniquely qualified for studies of both climate and air quality. However, the application of satellitebased datasets in climate studies strictly requires that those datasets be unaffected by bias variability which could be mis- 

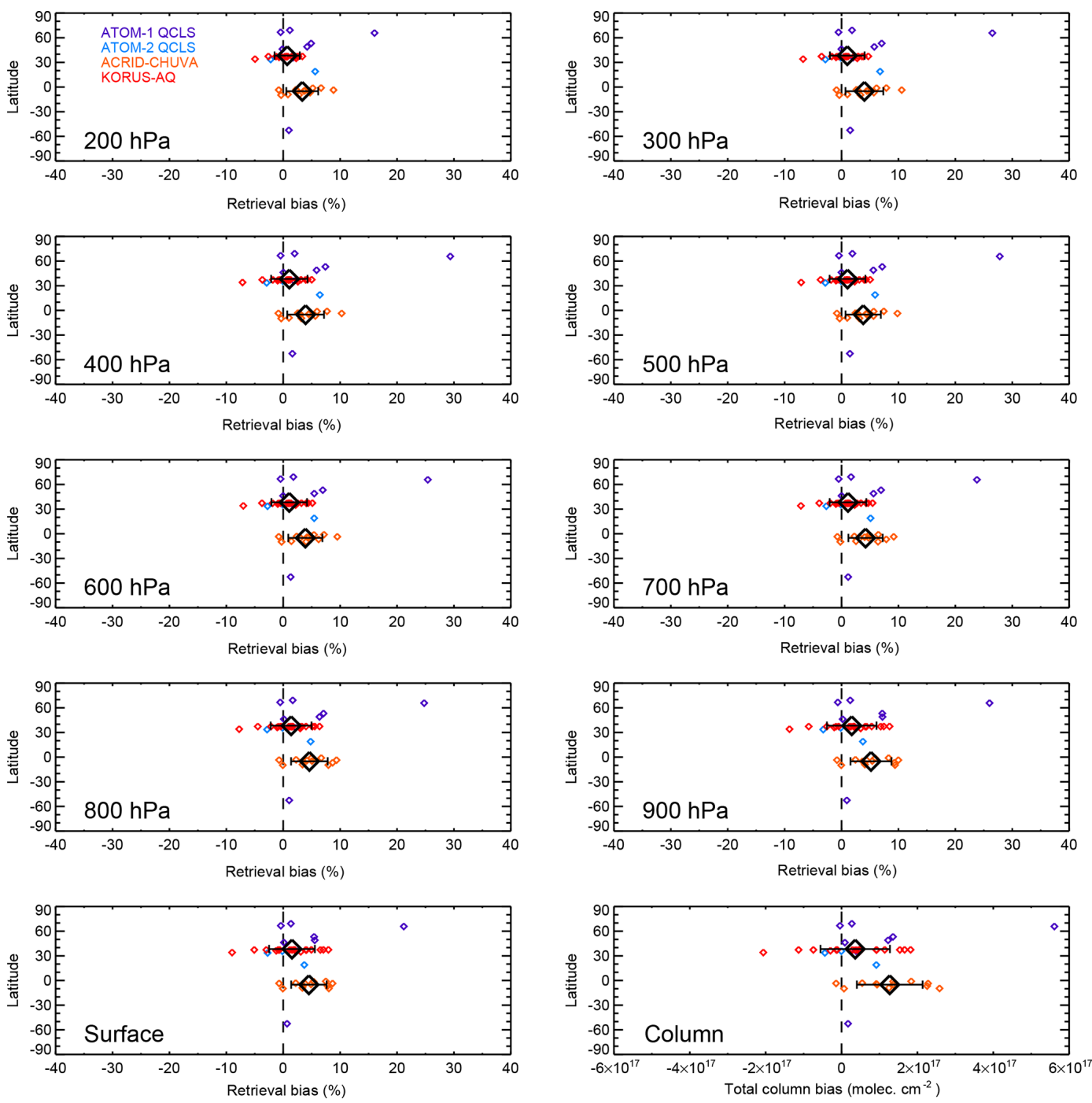

Figure 10. V8 NIR-only biases based on the ATom, ACRIDICON, and KORUS-AQ CO profiles.

interpreted as a geophysical (climate-related) signal. Thus, the systematic comparison of satellite datasets to long-term in situ datasets, as demonstrated above, is an essential prerequisite to the use of satellite data in climate studies.

Drifting retrieval bias evident in earlier MOPITT products could be the result of long-term instrumental degradation and/or temporal inconsistencies in the MERRA (and MERRA-2) temperature and water vapor profiles assumed in the MOPITT retrieval algorithm. Instrumental effects might include, for example, degradation in the sensors measuring the gas correlation cell temperatures and pressures and/or long-term composition changes within the gas correlation cells. The newest release of the MOPITT product, version 8 , incorporates an improved radiance bias correction method which sharply decreases both retrieval bias drift and bias geographical variability. The method involves a simple linear parameterization relating radiance biases in both the TIR and
NIR channels to (1) the number of elapsed days since the beginning of the mission and (2) the vertically integrated water vapor at the location of the satellite measurement. The new MOPITT V8 product also benefits from updated spectroscopic data for water vapor and nitrogen.

Our chosen strategy to rely on the stability of the NOAA aircraft in situ data to determine the time-dependent radiance bias correction factors does imply that the fidelity of $\mathrm{CO}$ trends in the radiance bias-corrected MOPITT data (i.e., the V8 retrieval product) is ultimately limited by the stability of the NOAA in situ measurements. However, the NOAA measurements are widely accepted as a standard for long-term $\mathrm{CO}$ analyses and are calibrated using the World Meteorological Organization (WMO) mole fraction scale (Sweeney et al., 2015). The NOAA dataset is therefore well qualified for climate analyses. On the other hand, we acknowledge that bias drift in the V8 product for regions not represented by the 

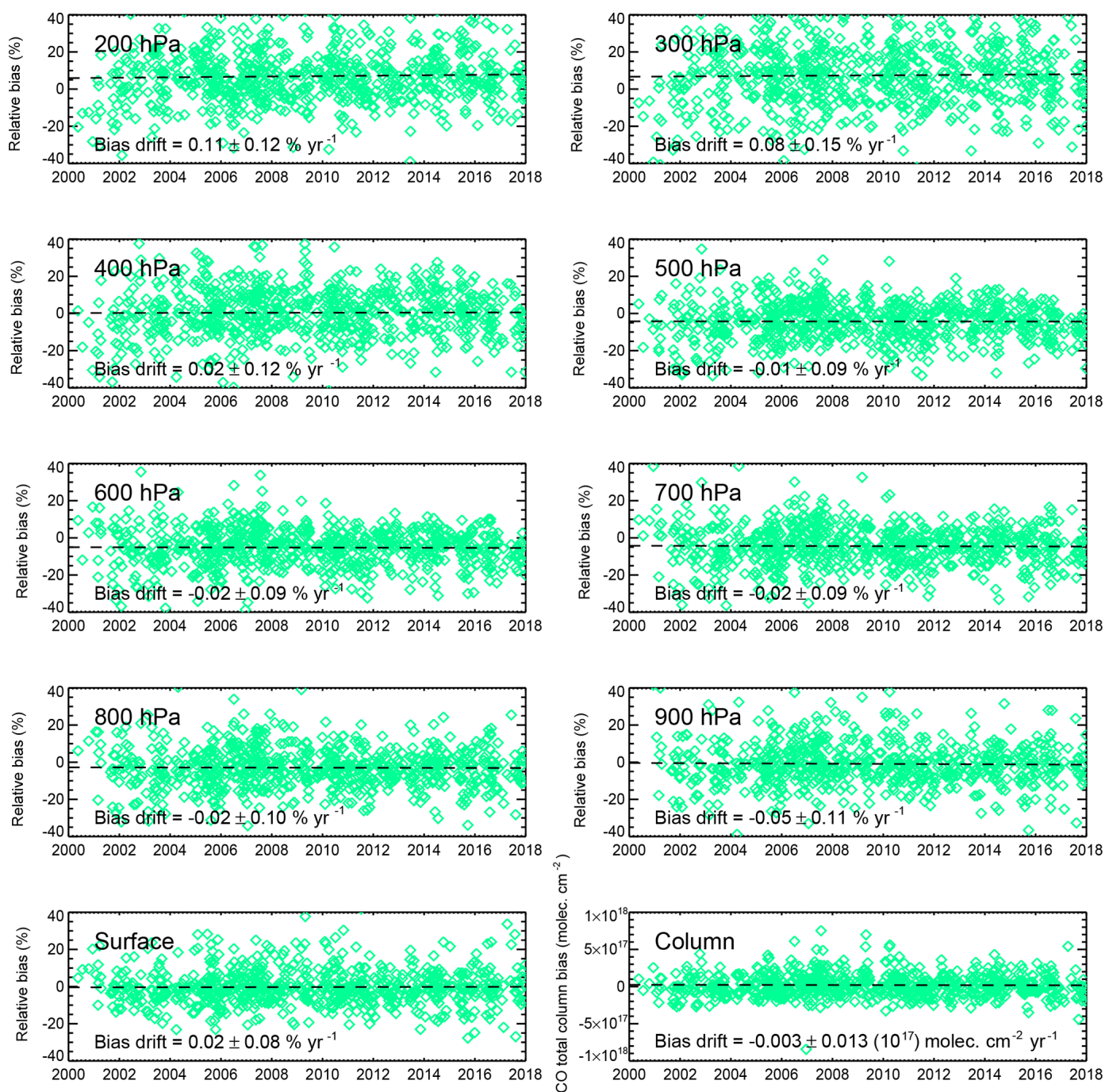

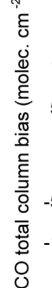

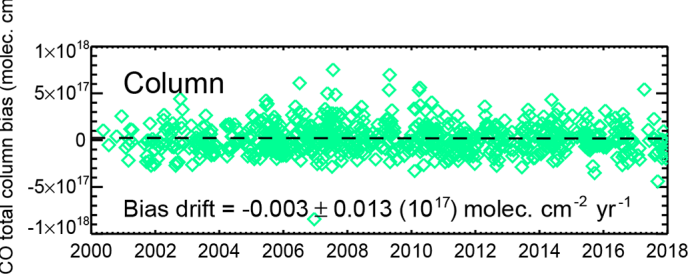

Figure 11. Retrieval bias drift for V8 TIR-NIR products based on the NOAA flask measurements.

NOAA aircraft network (primarily covering North America) could be substantially different. This seems unlikely though, particularly if the source of the bias is instrumental.

Validation results demonstrate that MOPITT V8 products, including TIR-only, NIR-only, and TIR-NIR variants, are typically characterized by biases of less than about $5 \%$, with bias drift generally less than $0.1 \% \mathrm{yr}^{-1}$. Geographically variable biases have also been substantially reduced compared to V7 products. Validation results for the AC, KORUS-AQ, and ATom campaigns, which were not involved in the development of the radiance bias correction method, are consistent with results for the NOAA and HIPPO profile sets. Ongoing validation work will include systematic comparisons of MOPITT products with other satellite products as well as ground-based remote sensing instruments.
Data availability. MOPITT version 8 products are freely available through NASA's EarthData portal at https://earthdata.nasa. gov/ (last access: 14 August 2019). NOAA in situ CO profiles are available at http://www.esrl.noaa.gov/gmd/ccgg/aircraft/ index.html (last access: 14 August 2019). In situ CO data from the HIPPO field campaign are available at http://hippo.ornl.gov/ dataaccess (last access: 14 August 2019). CO in situ data from the QCLS instrument during the ATom campaign are archived and publicly accessible from https://espoarchive.nasa.gov/archive/ browse/atom/DC8/QCLS-CH4-CO-N2O (last access: 14 August 2019). CO in situ data from the DACOM instrument during the KORUS-AQ campaign are archived and publicly accessible from https://www-air.larc.nasa.gov/cgi-bin/ArcView/korusaq (last access: 14 August 2019). The full dataset from the ACRIDICONCHUVA campaign is archived and publicly accessible from the HALO database maintained by the German Aerospace Center (DLR) at https://halo-db.pa.op.dlr.de/mission/5 (last access: $14 \mathrm{Au}$ gust 2019). 

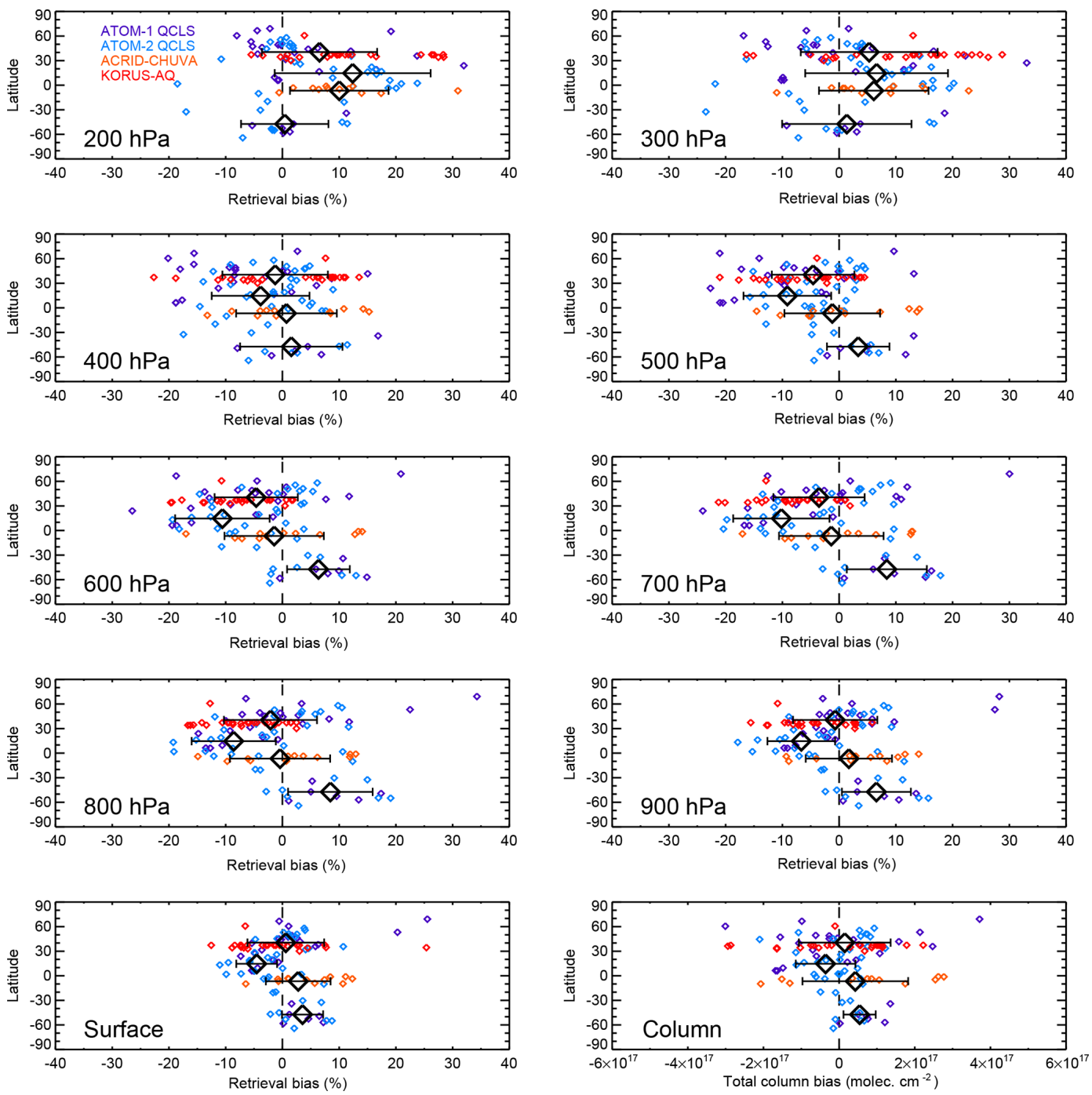

Figure 12. V8 TIR-NIR biases based on the ATom, ACRIDICON, and KORUS-AQ CO profiles.

Author contributions. MND led the development and validation of the MOPITT version 8 product and prepared the figures and manuscript. HMW, DPE, and GLF guided the changes made to the MOPITT radiative transfer model. SMA managed the validation datasets. JCG provided expertise with the MOPITT instrument. $\mathrm{DM}$ and DZ provided software engineering and data management support. MOA provided measurements from the ACRIDICONCHUVA experiment and assisted in their interpretation. All authors discussed the results and contributed to the final manuscript.

Competing interests. The authors declare that they have no conflict of interest.

Acknowledgements. The NCAR MOPITT project is supported by the National Aeronautics and Space Administration (NASA) Earth Observing System (EOS) Program. The National Center for At- mospheric Research (NCAR) is sponsored by the National Science Foundation.

We thank the ACRIDICON-CHUVA team for their cooperation during the AC campaign and the government of Brazil for permission to conduct the HALO flights. We acknowledge the support of the ACRIDICON-CHUVA campaign by the Max Planck Society, the German Aerospace Center (DLR), FAPESP (São Paulo Research Foundation), and the German Science Foundation (Deutsche Forschungsgemeinschaft, DFG) within the DFG Priority Program (SPP 1294) Atmospheric and Earth System Research with the Research Aircraft HALO (High Altitude and Long Range Research Aircraft).

Thanks are due also to the HIPPO and ATom science teams including Bruce Daube, Roisin Commane, Eric Kort, Greg Santoni, and Steve Wofsy and to the KORUS-AQ science team, particularly Glenn Diskin.

Finally, we also thank Colm Sweeney in NOAA's Global Monitoring Division for providing CO in situ profiles from the Global Greenhouse Gas Reference Network Aircraft Program. 
Financial support. This research has been supported by the NASA (grant no. NNG15HQ03C).

Review statement. This paper was edited by Gabriele Stiller and reviewed by four anonymous referees.

\section{References}

Buchholz, R. R., Deeter, M. N., Worden, H. M., Gille, J., Edwards, D. P., Hannigan, J. W., Jones, N. B., Paton-Walsh, C., Griffith, D. W. T., Smale, D., Robinson, J., Strong, K., Conway, S., Sussmann, R., Hase, F., Blumenstock, T., Mahieu, E., and Langerock, B.: Validation of MOPITT carbon monoxide using ground-based Fourier transform infrared spectrometer data from NDACC, Atmos. Meas. Tech., 10, 1927-1956, https://doi.org/10.5194/amt10-1927-2017, 2017.

Deeter, M. N., Emmons, L. K., Francis, G. L., Edwards, D. P., Gille, J. C., Warner, J. X., Khattatov, B., Ziskin, D., Lamarque, J.-F., Ho, S.-P., Yudin, V., Attié, J.-L., Packman, D., Chen, J., Mao, D., and Drummond, J. R.: Operational carbon monoxide retrieval algorithm and selected results for the MOPITT instrument, J. Geophys. Res., 108, 4399, https://doi.org/10.1029/2002JD003186, 2003.

Deeter, M. N., Edwards, D. P., Gille, J. C., and Drummond, J. R.: Sensitivity of MOPITT observations to carbon monoxide in the lower troposphere, J. Geophys. Res., 112, D24306, https://doi.org/10.1029/2007JD008929, 2007.

Deeter, M. N., Edwards, D. P., Gille, J. C., and Drummond, J. R.: CO retrievals based on MOPITT nearinfrared observations, J. Geophys. Res., 114, D04303, https://doi.org/10.1029/2008JD010872, 2009.

Deeter, M. N., Worden, H. M., Edwards, D. P., Gille, J. C., and Andrews, A. E.: Evaluation of MOPITT retrievals of lower-tropospheric carbon monoxide over the United States, J. Geophys. Res., 117, D13306, https://doi.org/10.1029/2012JD017553, 2012.

Deeter, M. N., Martínez-Alonso, S., Edwards, D. P., Emmons, L. K., Gille, J. C., Worden, H. M., Pittman, J. V., Daube, B. C., and Wofsy, S. C.: Validation of MOPITT Version 5 thermalinfrared, near-infrared, and multispectral carbon monoxide profile retrievals for 2000-2011, J. Geophys. Res.-Atmos., 118, 6710-6725, https://doi.org/10.1002/jgrd.50272, 2013.

Deeter, M. N., Martínez-Alonso, S., Edwards, D. P., Emmons, L. K., Gille, J. C., Worden, H. M., Sweeney, C., Pittman, J. V., Daube, B. C., and Wofsy, S. C.: The MOPITT Version 6 product: algorithm enhancements and validation, Atmos. Meas. Tech., 7, 3623-3632, https://doi.org/10.5194/amt-7-3623-2014, 2014.

Deeter, M. N., Martínez-Alonso, S., Gatti, L. V., Gloor, M., Miller, J. B., Domingues, L. G., and Correia, C. S. C.: Validation and analysis of MOPITT CO observations of the Amazon Basin, Atmos. Meas. Tech., 9, 3999-4012, https://doi.org/10.5194/amt-93999-2016, 2016.

Deeter, M. N., Edwards, D. P., Francis, G. L., Gille, J. C., Martínez-Alonso, S., Worden, H. M., and Sweeney, C.: A climate-scale satellite record for carbon monoxide: the MOPITT Version 7 product, Atmos. Meas. Tech., 10, 2533-2555, https://doi.org/10.5194/amt-10-2533-2017, 2017.
Drummond, J. R., Zou, J., Nichitiu, F., Kar, J., Deschambaut, R., and Hackett, J.: A review of 9-year performance and operation of the MOPITT instrument, Adv. Space Res., 45, 760-774, https://doi.org/10.1016/j.asr.2009.11.019, 2010.

Drummond, J. R., Hackett, J., and Caldwell, D.: Measurements Of Pollution In The Troposphere (MOPITT), in: Optical Payloads for Space Missions, edited by: Qian, S.-E., Wiley, West Sussex, UK, 2016.

Edwards, D. P.: GENLN2: A general line-by-line atmospheric transmittance and radiance model, Version 3.0 description and User's Guide, NCAR/TN-367+STR, NCAR Rep., Natl. Cent. for Atmos. Res., Boulder, Colorado, 1992.

Edwards, D. P., Halvorson, C. M., and Gille, J. C.: Radiative transfer modeling for the EOS Terra satellite Measurements of Pollution in the Troposphere (MOPITT) instrument, J. Geophys. Res., 104, 16755-16775, 1999.

Edwards, D. P., Emmons, L. K., Hauglustaine, D. A., Chu, D. A., Gille, J. C., Kaufman, Y. J., Pétron, G., Yurganov, L. N., Giglio, L., Deeter, M. N., Yudin, V., Ziskin, D. C., Warner, J., Lamarque, J.-F., Francis, G. L., Ho, S.-P., Mao, D., Chen, J., Grechko, E. I., and Drummond, J. R., Observations of carbon monoxide and aerosols from the Terra satellite: Northern Hemisphere variability, J. Geophys. Res., 109, D24202, https://doi.org/10.1029/2004JD004727, 2004.

Emmons, L. K., Walters, S., Hess, P. G., Lamarque, J.-F., Pfister, G. G., Fillmore, D., Granier, C., Guenther, A., Kinnison, D., Laepple, T., Orlando, J., Tie, X., Tyndall, G., Wiedinmyer, C., Baughcum, S. L., and Kloster, S.: Description and evaluation of the Model for Ozone and Related chemical Tracers, version 4 (MOZART-4), Geosci. Model Dev., 3, 43-67, https://doi.org/10.5194/gmd-3-43-2010, 2010.

Francis, G. L., Deeter, M. N., Martínez-Alonso, S., Gille, J. C., Edwards, D. P., Mao, D., Worden, H. M., and Ziskin, D.: Measurement of Pollution in the Troposphere Algorithm Theoretical Basis Document (ATBD), Retrieval of Carbon Monoxide Profiles and Column Amounts from MOPITT Observed Radiances, available at: https://www2.acom.ucar.edu/sites/default/ files/mopitt/ATBD_5_June_2017.pdf (last access: 14 August 2019), 2017.

Gaubert, B., Worden, H. M., Arellano, A. F., Emmons, L. K., Tilmes, S., Barre, J., Martínez-Alonso, S., Vitt, F., Anderson, J. L., Alkemade, F., Houweling, S., and Edwards, D. P.: Chemical Feedback From Decreasing Carbon Monoxide Emissions, Geophys. Res. Lett., 44, 9985-9995, https://doi.org/10.1002/2017GL074987, 2017.

Heald, C. L., Jacob, D. J., Fiore, A. M., Emmons, L. K., Gille, J. C., Deeter, M. N., Warner, J., Edwards, D. P., Crawford, J. H., Hamlin, A. J., Sachse, G. W., Browell, E. V., Avery, M. A., Vay, S. A., Westberg, D. J., Blake, D. R., Singh, H. B., Sandholm, S. T., Talbot, R. W., and Fuelberg, H. E.: Asian outflow and transPacific transport of carbon monoxide and ozone pollution: An integrated satellite, aircraft, and model perspective, J. Geophys. Res., 108, 4804, https://doi.org/10.1029/2003JD003507, 2003.

Inness, A., Blechschmidt, A.-M., Bouarar, I., Chabrillat, S., Crepulja, M., Engelen, R. J., Eskes, H., Flemming, J., Gaudel, A., Hendrick, F., Huijnen, V., Jones, L., Kapsomenakis, J., Katragkou, E., Keppens, A., Langerock, B., de Mazière, M., Melas, D., Parrington, M., Peuch, V. H., Razinger, M., Richter, A., Schultz, M. G., Suttie, M., Thouret, V., Vrekoussis, M., 
Wagner, A., and Zerefos, C.: Data assimilation of satelliteretrieved ozone, carbon monoxide and nitrogen dioxide with ECMWF's Composition-IFS, Atmos. Chem. Phys., 15, 52755303, https://doi.org/10.5194/acp-15-5275-2015, 2015.

Jiang, Z., Worden, J. R., Worden, H., Deeter, M., Jones, D. B. A., Arellano, A. F., and Henze, D. K.: A 15-year record of CO emissions constrained by MOPITT CO observations, Atmos. Chem. Phys., 17, 4565-4583, https://doi.org/10.5194/acp17-4565-2017, 2017.

Kopacz, M., Jacob, D. J., Fisher, J. A., Logan, J. A., Zhang, L., Megretskaia, I. A., Yantosca, R. M., Singh, K., Henze, D. K., Burrows, J. P., Buchwitz, M., Khlystova, I., McMillan, W. W., Gille, J. C., Edwards, D. P., Eldering, A., Thouret, V., and Nedelec, P.: Global estimates of $\mathrm{CO}$ sources with high resolution by adjoint inversion of multiple satellite datasets (MOPITT, AIRS, SCIAMACHY, TES), Atmos. Chem. Phys., 10, 855-876, https://doi.org/10.5194/acp-10-855-2010, 2010.

Kumar, R., Naja, M., Pfister, G. G., Barth, M. C., and Brasseur, G. P.: Source attribution of carbon monoxide in India and surrounding regions during wintertime, J. Geophys. Res.-Atmos., 118, 1981-1995, https://doi.org/10.1002/jgrd.50134, 2013.

Lamarque, J.-F., Emmons, L. K., Hess, P. G., Kinnison, D. E., Tilmes, S., Vitt, F., Heald, C. L., Holland, E. A., Lauritzen, P. H., Neu, J., Orlando, J. J., Rasch, P. J., and Tyndall, G. K.: CAM-chem: description and evaluation of interactive atmospheric chemistry in the Community Earth System Model, Geosci. Model Dev., 5, 369-411, https://doi.org/10.5194/gmd-5369-2012, 2012.

Martínez-Alonso, S., Deeter, M. N., Worden, H. M., Gille, J. C., Emmons, L. K., Pan, L., Park, M., Manney, G. L., Bernath, P. V., Boone, C. D., Walker, K. A., Kolonjari, F., Wofsy, S. C., Pittman, J., and Daube, B. C.: Comparison of upper tropospheric carbon monoxide from MOPITT, ACEFTS, and HIPPO-QCLS, J. Geophys. Res., 119, 14144-14164, https://doi.org/10.1002/2014JD022397, 2014.

Miyazaki, K., Sekiya, T., Fu, D., Bowman, K. W., Kulawik, S. S., Sudo, K., Walker, T., Kanaya, Y., Takigawa, M., Ogochi, K., Eskes, H., Boersma, K. F., Thompson, A. M., Gaubert, B., Barre, J., and Emmons, L. K.: Balance of emission and dynamical controls on ozone during KORUS-AQ from multi-constituent satellite data assimilation, J. Geophys. Res.-Atmos., 124, 387-413, https://doi.org/10.1029/2018JD028912, 2018.

Mlawer, E. J., Payne, V. H., Moncet, J.-L., Delamere, J. S., Alvarado, M. J., and Tobin, D. C.: Development and recent evaluation of the MT_CKD model of continuum absorption, Phil. T. Roy. Soc. A, 370, 2520-2556, https://doi.org/10.1098/rsta.2011.0295, 2012.

Moeller, C. and Frey, R.: Terra MODIS Collection 6.1 Calibration and Cloud Product Changes, Version 1.0, available at: https://modis-atmosphere.gsfc.nasa.gov/sites/default/files/ ModAtmo/C6.1_Calibration_and_Cloud_Product_Changes_ UW_frey_CCM_1.pdf (last access: 14 August 2019), 2017.

MOPITT Algorithm Development Team, MOPITT (Measurements of Pollution in the Troposphere) Version 8 Product User's Guide, available at: https://www2.acom.ucar.edu/sites/default/ files/mopitt/v8_users_guide_201812.pdf (last access: 14 August 2019), 2018.

Pan, L., Edwards, D. P., Gille, J. C., Smith, M. W., and Drummond, J. R.: Satellite remote sensing of tropospheric $\mathrm{CO}$ and $\mathrm{CH}_{4}$ : for- ward model studies of the MOPITT instrument, Appl. Opt., 34 6976-6988, 1995.

Pan, L., Gille, J., Edwards, D. P., Bailey, P. L., and Rodgers, C. D.: Retrieval of tropospheric carbon monoxide for the MOPITT instrument, J. Geophys. Res., 103, 32277-32290, 1998.

Pfister, G., Hess, P. G., Emmons, L. K., Lamarque, J.-F., Wiedinmyer, C., Edwards, D. P., Pétron, G., Gille, J. C., and Sachse, G. W.: Quantifying CO emissions from the 2004 Alaskan wildfires using MOPITT CO data, Geophys. Res. Lett., 32, 11809, https://doi.org/10.1029/2005GL022995, 2005.

Richard, C., Gordon, I. E., Rothman, L. S., Abel, M., Frommhold, L., Gustafsson, M., Hartmann, J.-M., Hermans, C., Lafferty, W. J., Ortong, G. S., Smith, K. M., and Tran, H.: New section of the HITRAN database: Collision-induced absorption (CIA), J. Quant. Spectrosc. Ra., 113, 1276-1285, https://doi.org/10.1016/j.jqsrt.2011.11.004, 2012.

Rodgers, C. D.: Inverse Methods for Atmospheric Sounding, Theory and Practice, World Scientific, Singapore, 2000.

Rodgers, C. D. and Connor, B. J.: Intercomparison of remote sounding instruments, J. Geophys. Res., 108, 4116, https://doi.org/10.1029/2002JD002299, 2003.

Rothman, L. S., Gordon, I. E., Babikov, Y., Barbe, A., Benner, D. C., Bernath, P. V., Birk, M., Bizzocchi, L., Boudon, V., Brown, L. R., Campargue, A., Chance, K., Cohen, E. A., Coudert, L. H., Devid, V. M., Drouin, B. J., Fayt, A., Flaud, J.-M., Gamache, R. R., Harrison, J. J., Hartmann, J.-M., Hill, C., Hodges, J. T., Jacquemart, D., Jolly, A., Lamouroux, J., Le Roy, R. J., Li, G., Long, D. A., Lyulin, O. M., Mackie, C. J., Massie, S. T., Mikhailenko, S., Müller, H. S. P., Naumenko, O. V., Nikitin, A. V., Orphal, J., Perevalov, V., Perrin, A., Polovtseva, E. R., Richard, C., Smith, M. A. H., Starikova, E., Sung, K., Tashkun, S., Tennyson, J., Toon, G. C., Tyuterev, V. G., and Wagner, G.: The HITRAN 2012 Molecular Spectroscopic Database, J. Quant. Spectrosc. Ra., 130, 4-50. https://doi.org/10.1016/j.jqsrt.2013.07.002, 2013.

Sachse, G. W., Hill, G. F., Wade, L. O., and Perry, M. G.: Fastresponse, high-precision carbon monoxide sensor using a tunable diode laser absorption technique, J. Geophys. Res., 92, 20712081, 1987.

Santoni, G. W., Daube, B. C., Kort, E. A., Jiménez, R., Park, S., Pittman, J. V., Gottlieb, E., Xiang, B., Zahniser, M. S., Nelson, D. D., McManus, J. B., Peischl, J., Ryerson, T. B., Holloway, J. S., Andrews, A. E., Sweeney, C., Hall, B., Hintsa, E. J., Moore, F. L., Elkins, J. W., Hurst, D. F., Stephens, B. B., Bent, J., and Wofsy, S. C.: Evaluation of the airborne quantum cascade laser spectrometer (QCLS) measurements of the carbon and greenhouse gas suite $-\mathrm{CO}_{2}, \mathrm{CH}_{4}, \mathrm{~N}_{2} \mathrm{O}$, and $\mathrm{CO}-$ during the CalNex and HIPPO campaigns, Atmos. Meas. Tech., 7, 1509-1526, https://doi.org/10.5194/amt-7-1509-2014, 2014.

Shindell, D. T., Faluvegi, G., Stevenson, D. S., Krol, M. C., Emmons, L. K., Lamarque, J.-F., Pétron, G., Dentener, F. J., Ellingsen, K., Schultz, M. G., Wild, O., Amann, M., Atherton, C. S., Bergmann, D. J., Bey, I., Butler, T., Cofala, J., Collins, W. J., Derwent, R. G., Doherty, R. M., Drevet, J., Eskes, H. J., Fiore, A. M., Gauss, M., Hauglustaine, D. A., Horowitz, L. W., Isaksen, I. S. A., Lawrence, M. G., Montanaro, V., Müller, J.-F., Pitari, G., Prather, M. J., Pyle, J. A., Rast, S., Rodriguez, J. M., Sanderson, M. G., Savage, N. H., Strahan, S. E., Sudo, K., Szopa, S., Unger, N., van Noije, T. P. C., and Zeng, G.: Multimodel simulations of carbon monoxide: Comparison with observations and 
projected near-future changes, J. Geophys. Res., 111, D19306, https://doi.org/10.1029/2006JD007100, 2006.

Sweeney, C., Karion, A., Wolter, S., Newberger, T., Guenther, D., Higgs, J. A., Andrews, A. E., Lang, P. M., Neff, D., Dlugokencky, E., Miller, J. B., Montzka, S. A., Miller, B. R., Masarie, K. A., Biraud, S. C., Novelli, P. C., Crotwell, M., Crotwell, A. M., Thoning, K., and Tans, P. P.: Seasonal climatology of $\mathrm{CO}_{2}$ across North America from aircraft measurements in the NOAA/ESRL Global Greenhouse Gas Reference Network, J. Geophys. Res., 120, 5155-5190, https://doi.org/10.1002/2014JD022591, 2015.

Turquety, S., Logan, J. A., Jacob, D. J., Hudman, R. C., Leung, F. Y., Heald, C. L., Yantosca, R. M., Wu, S., Emmons, L. K., Edwards, D. P., and Sachse, G. W.: Inventory of boreal fire emissions for North America in 2004: Importance of peat burning and pyroconvective injection, J. Geophys. Res., 112, D12S03, https://doi.org/10.1029/2006JD007281, 2007.

Wang, J., Gille, J. C., Bailey, P. L., Drummond, J. R., and Pan, L.: Instrument sensitivity and error analysis for the remote sensing of tropospheric carbon monoxide by MOPITT, J. Atmos. Ocean. Tech., 16, 465-474, 1999.

Wendisch, M., Pöschl, U., Andreae, M. O., Machado, L. A. T., Albrecht, R., Schlager, H., Rosenfeld, D., Martin, S. T., Abdelmonem, A., Afchine, A., Araùjo, A. C., Artaxo, P., Aufmhoff, H., Barbosa, H. M. J., Borrmann, S., Braga, R., Buchholz, B., Cecchini, M. A., Costa, A., Curtius, J., Dollner, M., Dorf, M., Dreiling, V., Ebert, V., Ehrlich, A., Ewald, F., Fisch, G., Fix, A., Frank, F., Fütterer, D., Heckl C., Heidelberg, F., Hüneke, T., Jäkel, E., Järvinen, E., Jurkat, T., Kanter, S., Kästner, U., Kenntner, M., Kesselmeier, J., Klimach, T., Knecht, M., Kohl, R., Kölling, T., Krämer, M., Krüger, M., Krisna, T. C., Lavric, J. V., Longo, K., Mahnke, C., Manzi, A. O., Mayer, B., Mertes, S., Minikin, A., Molleker, S., Münch, S., Nillius, B., Pfeilsticker, K., Pöhlker, C., Roiger, A., Rose, D., Rosenow, D., Sauer, D., Schnaiter, M., Schneider, J., Schulz, C., de Souza, R. A. F., Spanu, A., Stock, P., Vila, D., Voigt, C., Walser, A., Walter, D., Weigel, R., Weinzierl, B., Werner, F., Yamasoe, M. A., Ziereis, H., Zinner, T., and Zöger, M.: The ACRIDICON-CHUVA campaign: Studying tropical deep convective clouds and precipitation over Amazonia using the new German research aircraft HALO, B. Am. Meteorol. Soc., 97, 1885-1908, https://doi.org/10.1175/BAMS-D-14$00255.1,2016$.
Wofsy, S. C.: HIAPER Pole-to-Pole Observations (HIPPO): finegrained, global-scale measurements of climatically important atmospheric gases and aerosols, Phil. T. Roy. Soc. A, 369, 2073 2086, https://doi.org/10.1098/rsta.2010.0313, 2011.

Worden, H. M., Deeter, M. N., Edwards, D. P., Gille, J. C., Drummond, J. R., and Nédélec, P.: Observations of near-surface carbon monoxide from space using MOPITT multispectral retrievals, J. Geophys. Res., 115, D18314, https://doi.org/10.1029/2010JD014242, 2010.

Worden, H. M., Deeter, M. N., Frankenberg, C., George, M., Nichitiu, F., Worden, J., Aben, I., Bowman, K. W., Clerbaux, C., Coheur, P. F., de Laat, A. T. J., Detweiler, R., Drummond, J. R., Edwards, D. P., Gille, J. C., Hurtmans, D., Luo, M., Martínez-Alonso, S., Massie, S., Pfister, G., and Warner, J. X.: Decadal record of satellite carbon monoxide observations, Atmos. Chem. Phys., 13, 837-850, https://doi.org/10.5194/acp-13837-2013, 2013.

Worden, H. M., Deeter, M. N., Edwards, D. P., Gille, J., Drummond, J., Emmons, L. K., Francis, G., and Martínez-Alonso, S.: 13 years of MOPITT operations: lessons from MOPITT retrieval algorithm development, Ann. Geophys., 56, 1-5, https://doi.org/10.4401/ag-6330, 2014

Zheng, B., Chevallier, F., Ciais, P., Yin, Y., Deeter, M. N., Worden, H. M., Wang, Y., Zhang, Q., and He, K.: Rapid decline in carbon monoxide emissions and export from East Asia between years 2005 and 2016, Environ. Res. Lett., 13, 044007 , https://doi.org/10.1088/1748-9326/aab2b3, 2018. 